Supporting Information (SI) for the manuscript:

\title{
Multivariate Metal-Organic Frameworks for the Simultaneous Capture of Organic and Inorganic Contaminants from Water
}

\footnotetext{
Marta Mon, ${ }^{\dagger}$ Rosaria Bruno, ${ }^{\S}$ Estefania Tiburcio, ${ }^{\dagger}$ Marta VicianoChumillas, ${ }^{\dagger}$ Lucas H. G. Kalinke, ${ }^{\dagger,}$ Jesús Ferrando-Soria, ${ }^{*}{ }^{\dagger}$ Donatella Armentano*,§ and Emilio Pardo*,†

†Instituto de Ciencia Molecular (ICMol), Universidad de Valencia, 46980 Paterna, Valencia, Spain. ${ }^{\S}$ Dipartimento di Chimica e Tecnologie Chimiche (CTC), Università della Calabria, Rende 87036, Cosenza, Italy. \#nstituto Federal de Goiás-IFG, 75131-457, Anápolis, Goiás, Brazil
} 


\section{Experimental Section}

Materials. All chemicals were of reagent grade quality. They were purchased from commercial sources and used as received. Organic ligands $\left[\mathrm{H}_{2} \mathrm{Me}_{2}-(S, S)\right.$-methox and $\mathrm{H}_{2} \mathrm{Me}_{2}-(S, S)$-serimox $]$, dinuclear precursor complexes $\left[\left(\mathrm{Me}_{4} \mathrm{~N}\right)_{2}\left\{\mathrm{Cu}_{2}[(\mathrm{~S}, \mathrm{~S})-\right.\right.$ methox $\left.](\mathrm{OH})_{2}\right\} \cdot 4 \mathrm{H}_{2} \mathrm{O}$ and $\left(\mathrm{Me}_{4} \mathrm{~N}\right)_{2}\left\{\mathrm{Cu}_{2}[(\mathrm{~S}, \mathrm{~S})\right.$-serimox $\left.\left.](\mathrm{OH})_{2}\right\} \cdot 5 \mathrm{H}_{2} \mathrm{O}\right]$ and isoreticular MOFs $\quad\left\{\mathrm{Ca}^{\mathrm{II}} \mathrm{Cu}_{6}{ }_{6}[(S, S)-\text { methox }]_{3}(\mathrm{OH})_{2}\left(\mathrm{H}_{2} \mathrm{O}\right)\right\} \quad \cdot \quad 16 \mathrm{H}_{2} \mathrm{O} \quad(\mathbf{1 a}), \quad\left\{\mathrm{Ca}^{\mathrm{II}} \mathrm{Cu}_{6}{ }_{6}[(S, S)-\right.$ serimox $\left.]_{3}(\mathrm{OH})_{2}\left(\mathrm{H}_{2} \mathrm{O}\right)\right\} \cdot 39 \mathrm{H}_{2} \mathrm{O}(\mathbf{1 b})$ were prepared as previously reported. ${ }^{1,2}$

$\left.\left\{\mathrm{Ca}^{\mathrm{II}} \mathrm{Cu}^{\mathrm{II}}{ }_{6}[(S, S)-\text { methox }]_{1.43-1.46}(S, S) \text {-serimox }\right]_{1.57-1.54}(\mathrm{OH})_{2}\left(\mathrm{H}_{2} \mathrm{O}\right)\right\} \cdot 30 \mathrm{H}_{2} \mathrm{O}(2)$ $\left.\left\{\mathrm{Ba}^{\mathrm{II}} \mathrm{Cu}^{\mathrm{II}} 6[(S, S) \text {-methox }]_{1.41-1.45}(S, S) \text {-serimox }\right]_{1.59-1.55}(\mathrm{OH})_{2}\left(\mathrm{H}_{2} \mathrm{O}\right)\right\} \cdot 31 \mathrm{H}_{2} \mathrm{O}\left(2^{\prime}\right):$ Wellshaped hexagonal prisms of $\mathbf{2}$ and $\mathbf{2}$ ' suitable for SCXRD were obtained by slow diffusion in $\mathrm{H}$-shaped tubes of aqueous solutions containing stoichiometric amounts of $\left(\mathrm{Me}_{4} \mathrm{~N}\right)_{2}\left\{\mathrm{Cu}_{2}[(\mathrm{~S}, \mathrm{~S})\right.$-serimox $\left.](\mathrm{OH})_{2}\right\} \quad \cdot \quad 5 \mathrm{H}_{2} \mathrm{O} \quad(0.119 \quad \mathrm{~g}, \quad 0.18 \mathrm{mmol}) \quad$ and $\left(\mathrm{Me}_{4} \mathrm{~N}\right)_{2}\left\{\mathrm{Cu}_{2}[(\mathrm{~S}, \mathrm{~S})-\right.$ methox $\left.](\mathrm{OH})_{2}\right\} \cdot 4 \mathrm{H}_{2} \mathrm{O}(0.131 \mathrm{~g}, 0.18 \mathrm{mmol})$ in one arm and $\mathrm{CaCl}_{2}$ $2 \mathrm{H}_{2} \mathrm{O}(0.018 \mathrm{~g}, 0.12 \mathrm{mmol})$ or $\mathrm{BaCl}_{2} \cdot 2 \mathrm{H}_{2} \mathrm{O}(0.029 \mathrm{~g}, 0.12 \mathrm{mmol})$ in the other. They were isolated by filtration on paper and air-dried. Anal. calcd for 2: $\mathrm{C}_{29.84} \mathrm{Cu}_{6} \mathrm{CaS}_{2.92} \mathrm{H}_{99.68} \mathrm{~N}_{6} \mathrm{O}_{54.08}$ (1923.2): C, 18.64; H, 5.22; $\mathrm{S}, 4.87 ; \mathrm{N}, 4.37 \%$. Found: $\mathrm{C}$, 18.66; H, 5.20; S, 4.88; N, 4.36\%; IR (KBr): $v=1613$ and $1608 \mathrm{~cm}^{-1}(\mathrm{C}=\mathrm{O}) . \mathrm{C}, \mathrm{H}, \mathrm{N}$, $\mathrm{S}$, analyses gave a final formula of $\left\{\mathrm{Ca}^{\mathrm{II}} \mathrm{Cu}^{\mathrm{II}} 6[(S, S) \text {-methox }]_{1.46}(S, S)\right.$ serimox $\left.]_{1.54}(\mathrm{OH})_{2}\left(\mathrm{H}_{2} \mathrm{O}\right)\right\} \cdot 30 \mathrm{H}_{2} \mathrm{O}$. Anal. calcd for 2': $\mathrm{C}_{29.8} \mathrm{Cu}_{6} \mathrm{BaS}_{2.90} \mathrm{H}_{101.6} \mathrm{~N}_{6} \mathrm{O}_{55.10}$ (2037.53): C, 17.57; H, 5.03; S, 4.56; N, 4.12\%. Found: C, 17.59; H, 5.01; S, 4.55; N, 4.14\%; IR (KBr): $v=1611$ and $1606 \mathrm{~cm}^{-1}(\mathrm{C}=\mathrm{O}) . \mathrm{C}, \mathrm{H}, \mathrm{N}, \mathrm{S}$, analyses gave a final formula of $\left.\left\{\mathrm{Ba}^{\mathrm{II} C \mathrm{Cu}_{6}}{ }_{6}[(S, S) \text {-methox }]_{1.45}(S, S) \text {-serimox }\right]_{1.55}(\mathrm{OH})_{2}\left(\mathrm{H}_{2} \mathrm{O}\right)\right\} \cdot 31 \mathrm{H}_{2} \mathrm{O}$.

A gram-scale procedure was also carried out successfully by mixing greater amounts of $\left(\mathrm{Me}_{4} \mathrm{~N}\right)_{2}\left\{\mathrm{Cu}_{2}[(\mathrm{~S}, \mathrm{~S})\right.$-serimox $\left.](\mathrm{OH})_{2}\right\} \cdot 5 \mathrm{H}_{2} \mathrm{O}(2.375 \mathrm{~g}, 3.60 \mathrm{mmol})$ and $\left(\mathrm{Me}_{4} \mathrm{~N}\right)_{2}\left\{\mathrm{Cu}_{2}[(\mathrm{~S}, \mathrm{~S})\right.$-methox $\left.](\mathrm{OH})_{2}\right\} \cdot 4 \mathrm{H}_{2} \mathrm{O}(2.621 \mathrm{~g}, 3.60 \mathrm{mmol})$ in water $(40 \mathrm{~mL})$. 
Another aqueous solution of $\mathrm{CaCl}_{2} \cdot 2 \mathrm{H}_{2} \mathrm{O}(0.176 \mathrm{~g}, 1.20 \mathrm{mmol})$ was added dropwise to the resulting deep green solution and the final mix was allowed to react, under stirring, for 6 hours. Afterwards, the material was isolated by filtration and characterized by $\mathrm{C}$, $\mathrm{H}, \mathrm{N}, \mathrm{S}$, analyses to give a final formula of $\left\{\mathrm{Ca}^{\mathrm{II}} \mathrm{Cu}_{6}^{\mathrm{II}}[(S, S) \text {-methox }]_{1.43}(S, S)\right.$ serimox $\left.]_{1.57}(\mathrm{OH})_{2}\left(\mathrm{H}_{2} \mathrm{O}\right)\right\} \cdot 30 \mathrm{H}_{2} \mathrm{O}$ (2). Yield: 2.00 g, 87\%; Anal.: calcd for $\mathrm{C}_{29.72} \mathrm{Cu}_{6} \mathrm{CaS}_{2.86} \mathrm{H}_{99.44} \mathrm{~N}_{6} \mathrm{O}_{54.14}$ (1920.5): C, 18.59; H, 5.22; S, 4.78; N, 4.38\%. Found: $\mathrm{C}$, 18.58; H, 5.19; S, 4.77; N, 4.39\%; IR (KBr): $v=1611$ and $1609 \mathrm{~cm}^{-1}(\mathrm{C}=\mathrm{O})$. The same procedure was repeated by using $\mathrm{BaCl}_{2} \cdot 2 \mathrm{H}_{2} \mathrm{O}(0.293 \mathrm{~g}, 1.20 \mathrm{mmol})$ instead of $\mathrm{CaCl}_{2}$ $2 \mathrm{H}_{2} \mathrm{O}$ and another material was isolated by filtration and characterized by $\mathrm{C}, \mathrm{H}, \mathrm{N}, \mathrm{S}$, analyses to give a final formula of $\left\{\mathrm{Ba}^{\mathrm{II}} \mathrm{Cu}^{\mathrm{II}} 6[(S, S) \text {-methox }]_{1.41}(S, S)\right.$ serimox $\left.]_{1.59}(\mathrm{OH})_{2}\left(\mathrm{H}_{2} \mathrm{O}\right)\right\} \cdot 31 \mathrm{H}_{2} \mathrm{O} \quad\left(\mathbf{2}^{\prime}\right)$. Yield: $2.22 \mathrm{~g}$, 91\%; Anal.: calcd for $\mathrm{C}_{29.64} \mathrm{Cu}_{6} \mathrm{BaS}_{2.82} \mathrm{H}_{101.28} \mathrm{~N}_{6} \mathrm{O}_{55.18}$ (2034.0): $\mathrm{C}, 17.50 ; \mathrm{H}, 5.02 ; \mathrm{S}, 4.45 ; \mathrm{N}, 4.13 \%$. Found: C, 17.48; H, 4.97; S, 4.44; N, 4.14\%; IR (KBr): $v=1614$ and $1611 \mathrm{~cm}^{-1}(\mathrm{C}=\mathrm{O})$.

Preparation of

$(\mathrm{MB}) \cdot \mathrm{HgCl}_{2}\left\{\mathrm{Ca}^{\mathrm{II}} \mathrm{Cu}_{6}^{\mathrm{II}}[(S, S)-\operatorname{methox}]_{1.46}(S, S)-\right.$ serimox $\left.]_{1.54}(\mathrm{OH})_{2}\left(\mathrm{H}_{2} \mathrm{O}\right)\right\} \cdot 6 \mathrm{H}_{2} \mathrm{O}\left[(\mathrm{MB}) \cdot \mathbf{H g C l}_{2} @ 2\right]$ : Well-shaped hexagonal prisms of (MB)·HgCl $\mathbf{H} @ 2$, suitable for SCXRD, could be obtained by soaking crystals of 2 (5.0 mg) for a week in saturated aqueous solutions containing methylene blue and $\mathrm{HgCl}_{2}$ salt (recharging fresh saturated solutions daily). After this period, they were isolated by filtration, air-dried and characterized by $\mathrm{C}, \mathrm{H}, \mathrm{N}, \mathrm{S}$ and TGA analyses to give a final formula of $\left.(\mathrm{MB}) \cdot\left(\mathrm{HgCl}_{2}\right)\left\{\mathrm{Ca}^{\mathrm{II}} \mathrm{Cu}_{6}^{\mathrm{II}}[(\mathrm{S}, S) \text {-methox }]_{1.46}(S, S) \text {-serimox }\right]_{1.54}(\mathrm{OH})_{2}\left(\mathrm{H}_{2} \mathrm{O}\right)\right\}$ $6 \mathrm{H}_{2} \mathrm{O}$ (2). Anal.: calcd for $\mathrm{C}_{45.84} \mathrm{Cu}_{6} \mathrm{CaCl}_{3} \mathrm{HgS}_{3.92} \mathrm{H}_{69.68} \mathrm{~N}_{9} \mathrm{O}_{30.08}$ (2082.1): C, 26.44; $\mathrm{H}$, 3.37; S, 6.04; N, 6.05\%. Found: C, 26.41; H, 3.33; S, 6.07; N, 6.04\%; IR (KBr): $v=$ $1645(\mathrm{C}=\mathrm{N})$ and 1607 and $1609 \mathrm{~cm}^{-1}(\mathrm{C}=\mathrm{O})$.

Physical Techniques: Elemental (C, H, S, N), SEM-EDX and ICP-MS analyses were performed at the Microanalytical Service of the Universitat de València. FT-IR 
spectra were recorded on a Perkin-Elmer 882 spectrophotometer as $\mathrm{KBr}$ pellets. The thermogravimetric analyses were performed on crystalline samples under a dry $\mathrm{N}_{2}$ atmosphere with a Mettler Toledo TGA/STDA $851^{\mathrm{e}}$ thermobalance operating at a heating rate of $10{ }^{\circ} \mathrm{C} \mathrm{min}^{-1}$. UV-Vis spectra were recorded, at room temperature, with a Jasco V 670 spectrometer.

The $\mathrm{N}_{2}$ adsorption-desorption isotherms at $77 \mathrm{~K}$ were carried out on crystalline samples of 1a, 1b, 2 and 2' with a Micromeritics ASAP2020 instrument. Samples were activated at $70{ }^{\circ} \mathrm{C}$ under reduced pressure $\left(10^{-6}\right.$ Torr $)$ for $16 \mathrm{~h}$ prior to carry out the sorption measurements.

\section{Capture experiments:}

Kinetic profile of the capture of the organic dyes: In order to evaluate the kinetics and the efficiency of the capture process, $50 \mathrm{mg}$ of a polycrystalline sample of 2 were soaked in $20 \mathrm{~mL}$ of four aqueous solutions containing Pyronin Y (PY), Auramine $\mathrm{O}(\mathrm{AO})$, Brilliant Green (BG) and Methylene Blue (MB), respectively (10 $\mathrm{ppm}, \mathrm{pH} \approx 7.0$ ). Each mixture was stirred at room temperature and the concentration of the supernatant solutions were estimated through UV-vis spectroscopy at different time intervals (see main text). The same experiment was repeated, for each dye individually (Table S2 and Figures S9 and S10) and for a "multi-dye" solution containing $10 \mathrm{ppm}$ of each dye (Table S3 and Figures 3a and S11), in water.

Kinetic profile of the capture of the metal salts: In order to evaluate the kinetics of the capture processes (see text), $50 \mathrm{mg}$ of a polycrystalline sample of 2 were soaked in $20 \mathrm{~mL}$ of an aqueous solution of $\mathrm{Hg}\left(\mathrm{NO}_{3}\right)_{2}, \mathrm{~Pb}\left(\mathrm{NO}_{3}\right)_{2}, \mathrm{TlNO}_{3}, \mathrm{NaNO}_{3}, \mathrm{KNO}_{3}$, $\mathrm{Mg}\left(\mathrm{NO}_{3}\right)_{2}, \mathrm{Ca}\left(\mathrm{NO}_{3}\right)_{2}, \mathrm{Ni}\left(\mathrm{NO}_{3}\right)_{2}$ and $\mathrm{Cu}\left(\mathrm{NO}_{3}\right)_{2}(1 \mathrm{ppm}, \mathrm{pH} \approx 7.0)$. The mixture was stirred at room and $200 \mu \mathrm{L}$ aliquots were extracted at different time intervals (see Table 
S4 and Figures 2 and S12), the cation concentrations being estimated through ICP-MS analyses.

Kinetic profile of the capture of the organic dyes and metal salts from the multicomponent solution: $50 \mathrm{mg}$ of a polycrystalline sample of 2 were soaked in $20 \mathrm{~mL}$ an aqueous solution containing 1 ppm of $\mathrm{Hg}\left(\mathrm{NO}_{3}\right)_{2}, \mathrm{~Pb}\left(\mathrm{NO}_{3}\right)_{2}, \mathrm{TlNO}_{3}, \mathrm{NaNO}_{3}, \mathrm{KNO}_{3}$, $\mathrm{Mg}\left(\mathrm{NO}_{3}\right)_{2}, \mathrm{Ca}\left(\mathrm{NO}_{3}\right)_{2}, \mathrm{Ni}\left(\mathrm{NO}_{3}\right)_{2}$ and $\mathrm{Cu}\left(\mathrm{NO}_{3}\right)_{2}$ and 10 ppm of PY, $\mathrm{AO}, \mathrm{BG}$ and $\mathrm{MB}$. The mixture was stirred at room temperature and the concentration of each pollutant was estimated from the supernatant solutions through UV-vis spectroscopy (organic dyes) and ICP-MS analyses (metal salts) at different time intervals (see main text, Tables S5 and S6 and Figures 3b and S13-S15).

Recycling of 2: After the simultaneous capture experiments described above, both types of contaminants were completely extracted from $\mathbf{2}$ by suspending, consecutively, the loaded material in 2-mercaptoethanol and ethanol for 4 and 2 hours respectively. The resulting material - with formula $\left\{\mathrm{Ca}^{\mathrm{II}} \mathrm{Cu}_{6}{ }_{6}[(\mathrm{~S}, \mathrm{~S})-\mathrm{methox}]_{1.46}(\mathrm{~S}, \mathrm{~S})-\right.$ serimox $\left.]_{1.54}(\mathrm{OH})_{2}\left(\mathrm{H}_{2} \mathrm{O}\right)\right\} \cdot 12 \mathrm{H}_{2} \mathrm{O} \cdot 8 \mathrm{CH}_{3} \mathrm{CH}_{2} \mathrm{OH}-$ was characterized by elemental analysis: Anal.: calcd for $\mathrm{C}_{45.84} \mathrm{Cu}_{6} \mathrm{CaS}_{2.92} \mathrm{H}_{111.68} \mathrm{~N}_{6} \mathrm{O}_{44.08}$ (1967.4): C, 27.98; H, 5.72; $\mathrm{S}$, 4.76; N, 4.27\%. Found: C, 27.94; H, 5.69; S, 4.79; N, 4.30\%. In order to determine the reusability of this material, $50 \mathrm{mg}$ of this recycled polycrystalline sample of 2 were soaked in $20 \mathrm{~mL}$ of an aqueous solution containing 1 ppm of $\mathrm{Hg}\left(\mathrm{NO}_{3}\right)_{2}, \mathrm{~Pb}\left(\mathrm{NO}_{3}\right)_{2}$, $\mathrm{TlNO}_{3}, \mathrm{NaNO}_{3}, \mathrm{KNO}_{3}, \mathrm{Mg}\left(\mathrm{NO}_{3}\right)_{2}, \mathrm{Ca}\left(\mathrm{NO}_{3}\right)_{2}, \mathrm{Ni}\left(\mathrm{NO}_{3}\right)_{2}$ and $\mathrm{Cu}\left(\mathrm{NO}_{3}\right)_{2}$ and $10 \mathrm{ppm}$ of $\mathrm{PY}, \mathrm{AO}, \mathrm{BG}$ and $\mathrm{MB}$. The mixture was stirred at room temperature and the concentration of each pollutant was estimated from the supernatant solutions through UV-vis spectroscopy (organic dyes) and ICP-MS analyses (metal salts) at different time intervals (see main text, Tables S7 and S8). 
Kinetic profile of the simultaneous capture of the organic dyes and metal salts from the multicomponent solution by a mixture of $\mathbf{1 a}$ and $\mathbf{1 b}$ : $50 \mathrm{mg}$ of a mixture of polycrystalline samples of $\mathbf{1 a}(25 \mathrm{mg})$ and $\mathbf{1 b}(25 \mathrm{mg})$ were soaked in $20 \mathrm{~mL}$ of an aqueous solution containing 1 ppm of $\mathrm{Hg}\left(\mathrm{NO}_{3}\right)_{2}, \mathrm{~Pb}\left(\mathrm{NO}_{3}\right)_{2}, \mathrm{TINO}_{3}, \mathrm{NaNO}_{3}, \mathrm{KNO}_{3}$, $\mathrm{Mg}\left(\mathrm{NO}_{3}\right)_{2}, \mathrm{Ca}\left(\mathrm{NO}_{3}\right)_{2}, \mathrm{Ni}\left(\mathrm{NO}_{3}\right)_{2}$ and $\mathrm{Cu}\left(\mathrm{NO}_{3}\right)_{2}$ and 10 ppm of PY, $\mathrm{AO}, \mathrm{BG}$ and $\mathrm{MB}$. The mixture was stirred at room temperature and the concentration of each pollutant was estimated from the supernatant solutions through UV-vis spectroscopy (organic dyes) and ICP-MS analyses (metal salts) at different time intervals (see main text, Tables S9 and S10).

\section{X-ray crystallographic data collection and structure refinement: Crystals of 2, 2'} and (MB)·HgCl $\mathbf{2} @ 2$ were selected and mounted on a MITIGEN holder in Paratone oil. Crystals of $\mathbf{2}$ and 2' were very quickly placed in a nitrogen stream cooled at $100 \mathrm{~K}$ to avoid the possible degradation upon desolvation or exposure to air whereas crystals of (MB)·HgCl $\mathbf{H} @ 2$ aggregates were measured at $296 \mathrm{~K}$, without displaying any kind of crystal decay, to further test their stability at air and room temperature. Diffraction data for 2' were collected using synchrotron radiation at I19 beamline of the Diamond Light Source at $\lambda=0.6889 \AA$, whereas for $\mathbf{2}$ and $(\mathbf{M B}) \cdot \mathbf{H g C l} \mathbf{2} @ \mathbf{2}$ data were acquired on a Bruker-Nonius X8APEXII CCD area detector diffractometer using graphitemonochromated Mo- $\mathrm{K}_{\alpha}$ radiation $(\lambda=0.71073 \AA)$. The data were processed through xia2 $\left(\mathbf{2}^{\prime}\right){ }^{3}$ or $\mathrm{SAINT}^{4}$ reduction and $\mathrm{SADABS}^{5}$ multi-scan absorption $[2$ and (MB)·HgCl $\mathbf{H}_{2} @ 2$ 2] software. The structures were solved with the SHELXS structure solution program, using the Patterson method. The model was refined with version 2018/3 of SHELXL against $F^{2}$ on all data by full-matrix least squares. ${ }^{6}$

It is worth to note that $(\mathbf{M B}) \cdot \mathbf{H g C l}_{2} @ \mathbf{2}$ crystals were previously measured in a SCXR Diffractometer in synchrotron at I19 beamline of the Diamond Light Source $(\lambda=$ 
$0.6889 \AA$ A) with poorest results mostly due to fast crystal deterioration under synchrotron beam radiation. Bearing in mind that crystal structure of compound $(\mathbf{M B}) \cdot \mathbf{H g C l}_{2} @ 2$ has been obtained measuring on crystals which suffered a single-crystal to single-crystal (SC to SC) process, it is reasonable. On the other hand, we measured on the highest quality crystals we had, in synchrotron, related to sample 2', (containing the heavier alkaline-earth metal ion $\mathrm{Ba}^{2+}$ instead of $\mathrm{Ca}^{2+}$ ) before loading guests in order to go deep in the point of statistical disorder we observe both in $\mathbf{2}$ and $(\mathbf{M B}) \cdot \mathbf{H g C l} \mathbf{2} @ \mathbf{2}$ where crystallographic analysis does give superimposed snapshots of reactant dimers averaged in mixed $\left\{\mathrm{Cu}_{2}{ }_{2}[(\mathrm{~S}, \mathrm{~S})\right.$-methox/serimox $\left.]\right\}$ ones. Despite the highest data quality of data set measured up to theta $36^{\circ}$ (see Table S1), no appreciable variations in final model of crystal structure has been achieved for 2' (see Figures S4-S5).

In all samples, all non-hydrogen atoms were refined anisotropically except some highly dynamically disordered atoms of guest molecules in $(\mathbf{M B}) \cdot \mathbf{H g C l}_{\mathbf{2}} @ 2$. The use of some bond lengths restraints applied on atoms belonging to highly dynamic moieties especially during the refinements in (MB)·HgCl $\mathbf{H} @ \mathbf{2}$ has been reasonably imposed and related to the expected thermal motion likely depending on the large size of the huge cages of the frameworks (SADI, DFIX, DANG, SIMU, DELU and ISOR). In the refinement of 2' the sulphur atoms of methionine residues have been found disordered on two sites and refined using PART command on occupancy factors as well. In the refinement of $(\mathbf{M B}) \cdot \mathbf{H g C l} \mathbf{l}_{2} @ \mathbf{2}$ crystal structure some further restrains, to make the refinement more efficient, have been applied, for instance ADP components have been restrained to be similar to other related atoms, using SIMU 0.04 for disordered sections or EADP for group of atoms of the guest molecules expected to have essentially similar ADPs. All the hydrogen atoms of the net were set in calculated position and refined isotropically using the riding model. Hydrogen atoms on the guest molecules, and for 
found solvent lattice molecules were neither found nor calculated. These molecules are expected to be severely disordered as a direct consequence of their high thermal motion and exhibit also statistic disorder. As stated in main text, the oxamidato-bridged dicopper(II) units of $\left\{\mathrm{Cu}^{\mathrm{II}}{ }_{2}[(\mathrm{~S}, \mathrm{~S})\right.$-serimox $\left.]\right\}$ and $\left\{\mathrm{Cu}_{2}{ }_{2}[(\mathrm{~S}, \mathrm{~S})-\right.$-methox $\left.]\right\}$ inserted with a 1:1 ratio in 2 exhibit a statistically disorder in the crystal structure (Figure S1c), where the very similar percentage of serimox and methox leads to a completely superimposed snapshot of mixed $\left\{\mathrm{Cu}^{\mathrm{II}} 2[(\mathrm{~S}, \mathrm{~S})\right.$-methox/serimox $\left.]\right\}$ dimers, synchrotron measurements on 2' sample unveiled the same issue for its crystal structure. For further details on an alternative 2' model see below the section "Further Details on Crystallographic Refinements". In fact, a such disorder gives a mixed view of 2, understandable considering that a crystal structure is the spatial average, of all molecules/fragments, together with all their possible orientations averaged, in the crystal via only one unit cell.

In (MB)· $\mathrm{HgCl}_{2} @ 2$ the occupancies of the methylene blue and $\mathrm{HgCl}_{2}$ guests in the pores, have been defined by UV-vis measurements and ICP-MS analyses for organic and inorganic pollutants, respectively and thus imposed as real occupancy factors in structures refinement. We strongly believe that it is the more reliable way to accurately define loading instead of taking into account merely thermal factors, which can be affected by a lot of issues above all severe disorder.

In (MB)·HgCl $\mathbf{H} @ 2$, methylene blue guest molecules are statistically disordered as well exhibiting two set of possible orientations of the guest molecules as detailed in Figures S17, S18 and S19.

Moreover, $\mathrm{Cl}^{-}$counter-anions and the $-\mathrm{N}\left(\mathrm{CH}_{3}\right)_{2}$ terminal groups could not be found from $\Delta \mathrm{F}$ map, which is probably related to the different degrees of freedom, related to diverse possible conformations. In particular, the partial overlap between different 
orientations at C5L and C12L make them disordered with carbon sites (see Figure S19). The contribution to the diffraction pattern from the highly disordered solvent molecules (2 and 2'), undetected terminal groups and $\mathrm{Cl}$ - anions [(MB)·HgCl $\mathbf{2} @ \mathbf{2}]$ located in the voids was subtracted from the observed data through the SQUEEZE method, implemented in PLATON. ${ }^{7}$

Without found solvent molecules, the effective free volumes of $\mathbf{2}$ and 2' are calculated by PLATON analysis to be $41.7 \%$ and $45.6 \%$ of the crystal volume (1458.0 and $1675.3 \AA^{3}$ of the 3498.0 and $3670.5 \AA^{3}$ of the unit cell volume for $\mathbf{2}$ and 2', respectively). In accordance with BET and SCXRD analysis, the channels of 2 are almost entirely filled by inorganic and organic molecular guests that, together with very few and strongly enlaced solvent molecules, account for close to 93\% (1203 $\left.\mathrm{A}^{3}\right)$ of the empty volume available.

A summary of the crystallographic data and structure refinement for the three compounds is given in Table S1. The comments for the alerts A and B are described in the CIFs using the validation reply form (vrf). CCDC reference numbers are 19219281921930 for 2, 2' and (MB)·HgCl $\mathbf{2} @ \mathbf{2}$, respectively.

The final geometrical calculations on free voids and the graphical manipulations were carried out with PLATON ${ }^{7}$ implemented in WinGX, ${ }^{8}$ and CRYSTAL MAKER ${ }^{9}$ programs, respectively.

Further Details on Crystallographic Refinements: Undoubtedly the best refinement was achieved modelling mixed serine/methionine dimers. Furthermore, for the sake of clarity we depicted those mixed dimers in order to evaluate and more clearly show the binding sites responsible of host-guest interactions. However, the most 'realistic' situation within crystals of these MTV-MOFs is, of course, a randomly distribution of serine and methionine moieties (with 1:1 ratio) within the net. 
Thus, an alternative model refinement on high quality data of 2' has been performed taking into account of all positional disorder and consequent shared sites/positions for some carbon and oxygen atoms belonging to serine and methionine residues with EXYZ command of SHELX software package (see Scheme 2). Unfortunately, a similar treatment gave unstable or poorest refinement for $\mathbf{2}$ and $(\mathbf{M B}) \cdot \mathbf{H g C l}_{\mathbf{2}} @ \mathbf{2}$.

In so doing, found water molecules only enlaced with serine moieties (and virtually overlapping with methionine ones) have been modelled with occupancy factors related to those of serine residues.

X-ray Powder Diffraction Measurements: A fresh polycrystalline sample of $\mathbf{2}$ and 2' were introduced into $0.5 \mathrm{~mm}$ borosilicate capillaries prior to being mounted and aligned on a Empyrean PANalytical powder diffractometer, using $\mathrm{Cu} \mathrm{K} \alpha$ radiation $(\lambda=$ $1.54056 \AA$ A). For each sample, five repeated measurements were collected at room temperature $\left(2 \theta=2-60^{\circ}\right)$ and merged in a single diffractogram. 
Table S1. Summary of Crystallographic Data for 2, 2' and (MB)· $\mathrm{HgCl}_{2} @ 2$

\begin{tabular}{|c|c|c|c|}
\hline Compound & 2 & 2 & $(\mathrm{MB}) \cdot \mathrm{HgCl}_{2} @ 2$ \\
\hline Formula & $\mathrm{C}_{30} \mathrm{H}_{100} \mathrm{CaCu}_{6} \mathrm{~N}_{6} \mathrm{O}_{55} \mathrm{~S}_{3}$ & $\mathrm{C}_{30} \mathrm{H}_{102} \mathrm{CaCu}_{6} \mathrm{~N}_{6} \mathrm{O}_{56} \mathrm{~S}_{3}$ & $\mathrm{C}_{42} \mathrm{H}_{70} \mathrm{CaCu}_{6} \mathrm{Cl}_{3} \mathrm{HgN}_{7} \mathrm{O}_{30} \mathrm{~S}_{4}$ \\
\hline$M\left(\mathrm{~g} \mathrm{~mol}^{-1}\right)$ & 1942.65 & 2057.93 & 2009.55 \\
\hline$\lambda(\AA)$ & 0.71073 & 0.6889 & 0.71073 \\
\hline Crystal system & hexagonal & hexagonal & hexagonal \\
\hline Space group & $P 6_{3}$ & $\mathrm{PG}_{3}$ & $\mathrm{PG}_{3}$ \\
\hline$a(\AA)$ & $17.7932(12)$ & $17.90660(4)$ & $17.969(4)$ \\
\hline$c(\AA)$ & $12.7581(8)$ & $13.21800(6)$ & $12.949(4)$ \\
\hline$V\left(\AA^{3}\right)$ & $3498.0(5)$ & $3670.48(2)$ & $3620.8(19)$ \\
\hline$Z$ & 2 & 2 & 2 \\
\hline$\rho_{\text {calc }}\left(\mathrm{g} \mathrm{cm}^{-3}\right)$ & 1.844 & 1.862 & 1.843 \\
\hline$\mu\left(\mathrm{mm}^{-1}\right)$ & 2.074 & 2.141 & 4.218 \\
\hline$T(\mathrm{~K})$ & 100 & 100 & 296 \\
\hline $\begin{array}{l}\theta \text { range for data } \\
\text { collection }\left(^{\circ}\right)\end{array}$ & 2.644 to 26.354 & 1.273 to 36.006 & 0.998 to 26.086 \\
\hline $\begin{array}{l}\text { Completeness to } \theta= \\
25.0\end{array}$ & $100 \%$ & $100 \%$ & $100 \%$ \\
\hline Measured reflections & 32781 & 80907 & 29685 \\
\hline $\begin{array}{l}\text { Unique reflections } \\
\text { (Rint) }\end{array}$ & $4712(0.0532)$ & $12169(0.0417)$ & $4525(0.0442)$ \\
\hline $\begin{array}{l}\text { Observed reflections }[I \\
>2 \sigma(I)]\end{array}$ & 3718 & 7818 & 3247 \\
\hline Goof & 1.058 & 0.944 & 1.032 \\
\hline $\begin{array}{l}\text { Absolute structure } \\
\text { parameter (Flack) }\end{array}$ & $0.45(2)$ & $0.15(1)$ & $0.34(2)$ \\
\hline$R^{a}[I>2 \sigma(I)]$ (all data) & $0.0601(0.0704)$ & $0.0603(0.0823)$ & $0.0826(0.1120)$ \\
\hline$w R^{b}[I>2 \sigma(I)]$ (all data) & $0.1831(0.1923)$ & $0.1762(0.1889)$ & $0.2409(0.2735)$ \\
\hline
\end{tabular}

${ }^{a} R=\sum\left(\left|F_{\mathrm{o}}\right|-\left|F_{\mathrm{c}}\right|\right) / \sum\left|F_{\mathrm{o}}\right|{ }^{b} w R=\left[\sum w\left(\left|F_{\mathrm{o}}\right|-\left|F_{\mathrm{c}}\right|\right)^{2} / \sum w\left|F_{\mathrm{o}}\right|^{2}\right]^{1 / 2}$. 
Table S2. Selected data ${ }^{a}$ for the capture process, obtained from the UV-vis measurements for the aqueous solutions (mineral water) containing $10 \mathrm{ppm}$ of $\mathrm{PY}, \mathrm{AO}, \mathrm{BG}$ and $\mathrm{MB}$ after soaking $50 \mathrm{mg}$ of a polycrystalline sample of 2 .

\begin{tabular}{ccccc}
\hline Time (min.) & Pyronin $(\%)$ & Auramine O (\%) & Brilliant Green (\%) & Methylene Blue (\%) \\
\hline 1 & 74.83 & 72.48 & 72.47 & \\
5 & 81.99 & 77.22 & 84.08 & 87.54 \\
15 & 89.94 & 85.60 & 90.90 & 82.67 \\
30 & 93.85 & 91.88 & 94.68 & 87.97 \\
60 & 96.81 & 95.49 & 97.72 & 96.35 \\
1440 & 97.97 & 98.51 & 98.69 & 98.75
\end{tabular}

${ }^{a}$ Dye uptake (in \%) extracted from the UV-vis measurements. 
Table S3. Selected data ${ }^{a}$ for the capture process, obtained from the UV-vis measurements, for a multi-dye aqueous solution (mineral water) containing $10 \mathrm{ppm}$ of each dye (PY, AO, BG and MB), after soaking 50 $\mathrm{mg}$ of a polycrystalline sample of 2 .

\begin{tabular}{ccccc}
\hline Time (min.) & Pyronin $(\%)$ & Auramine O (\%) & Brilliant Green (\%) & Methylene Blue (\%) \\
\hline 1 & 79.54 & 76.08 & 79.88 & 77.08 \\
5 & 87.67 & 86.33 & 85.93 & 82.97 \\
15 & 91.97 & 92.1 & 95.93 & 90.56 \\
60 & 96.35 & 95.42 & 97.65 & 94.52 \\
360 & 98.88 & 97.36 & 98.64 & 96.84 \\
1440 & 99.13 & 98.27 & 98.95 & 98.11 \\
& & & &
\end{tabular}

${ }^{a}$ Dye uptake (in \%) extracted from the UV-vis measurements. 
Table S4. Selected data from the ICP-MS analyses ${ }^{\mathrm{a}, \mathrm{b}}$ for the aqueous mother solution during the adsorption process in a ca. 1 ppm aqueous solution of $\mathrm{Hg}\left(\mathrm{NO}_{3}\right)_{2}, \mathrm{~Pb}\left(\mathrm{NO}_{3}\right)_{2}, \mathrm{TlNO}_{3}, \mathrm{NaNO}_{3}, \mathrm{KNO}_{3}$, $\mathrm{Mg}\left(\mathrm{NO}_{3}\right)_{2}, \mathrm{Ca}\left(\mathrm{NO}_{3}\right)_{2}, \mathrm{Ni}\left(\mathrm{NO}_{3}\right)_{2}$ and $\mathrm{Cu}\left(\mathrm{NO}_{3}\right)_{2}$ after soaking $50 \mathrm{mg}$ of a polycrystalline sample of 2.

\begin{tabular}{|c|c|c|c|c|c|c|c|c|c|}
\hline $\begin{array}{l}\text { Time } \\
\text { (min.) }\end{array}$ & $\mathrm{Hg}^{2+}$ & $P b^{2+}$ & $T l^{+}$ & $\mathrm{Na}^{+}$ & $K^{+}$ & $M g^{2+}$ & $\mathrm{Ca}^{2+}$ & $N i^{2+}$ & $\mathrm{Cu}^{2+}$ \\
\hline 0 & 1059 & 1032 & 1132 & 987 & 1023 & 1002 & 1078 & 967 & 1013 \\
\hline 1 & 860 & 983 & 999 & 982 & 988 & 994 & 978 & 986 & 1012 \\
\hline 5 & 367 & 914 & 996 & 959 & 999 & 979 & 988 & 1013 & 987 \\
\hline 10 & 298 & 846 & 954 & 934 & 1013 & 1003 & 981 & 988 & 973 \\
\hline 15 & 146 & 674 & 876 & 1012 & 986 & 1001 & 979 & 963 & 933 \\
\hline 30 & 14.3 & 345 & 545 & 988 & 1011 & 1012 & 972 & 953 & 931 \\
\hline 45 & 13.9 & 277 & 511 & 1015 & 1000 & 979 & 1009 & 946 & 940 \\
\hline 60 & 8.82 & 112 & 412 & 998 & 999 & 1013 & 984 & 950 & 950 \\
\hline 90 & 7.02 & 65.4 & 365 & 1011 & 978 & 1002 & 983 & 949 & 939 \\
\hline 120 & 6.99 & 31.2 & 131 & 987 & 992 & 987 & 1001 & 958 & 929 \\
\hline 150 & 5.33 & 6.53 & 65.7 & 1025 & 988 & 979 & 987 & 950 & 939 \\
\hline 180 & 4.88 & 6.13 & 45.2 & 968 & 981 & 996 & 998 & 961 & 921 \\
\hline 210 & 5.12 & 6.47 & 29.51 & 1013 & 1010 & 1013 & 1011 & 948 & 939 \\
\hline 240 & 5.22 & 6.02 & 14.40 & 1020 & 979 & 983 & 987 & 951 & 932 \\
\hline 270 & 5.03 & 5.97 & 8.75 & 1004 & 972 & 987 & 968 & 942 & 939 \\
\hline 300 & 4.77 & 5.85 & 8.54 & 970 & 998 & 992 & 1020 & 951 & 931 \\
\hline 330 & 4.89 & 5.98 & 8.34 & 990 & 1009 & 1002 & 970 & 940 & 942 \\
\hline 360 & 4.82 & 6.00 & 7.77 & 1012 & 984 & 1011 & 1010 & 950 & 928 \\
\hline 720 & 5.12 & 6.12 & 8.02 & 988 & 983 & 989 & 988 & 943 & 927 \\
\hline 1440 & 5.00 & 5.89 & 8.04 & 991 & 1001 & 1001 & 981 & 947 & 930 \\
\hline 2880 & 5.11 & 5.94 & 7.89 & 1028 & 987 & 996 & 1010 & 946 & 934 \\
\hline
\end{tabular}

${ }^{a}$ Metal adsorption (wt. \%) extracted from the ICP-MS analyses. Results are given as $\mu$ g/L. ${ }^{\text {b }}$ L.D.: 0.012 $\mu \mathrm{g} / \mathrm{L}$. 
Table S5. Selected data $^{a}$ for the capture process of organic dyes, obtained from the UV-vis measurements, for one single aqueous solution (mineral water) containing $10 \mathrm{ppm}$ of PY, AO, BG and $\mathrm{MB}$ and 1 ppm of $\mathrm{Hg}\left(\mathrm{NO}_{3}\right)_{2}, \mathrm{~Pb}\left(\mathrm{NO}_{3}\right)_{2}, \mathrm{TlNO}_{3}, \mathrm{NaNO}_{3}, \mathrm{KNO}_{3}, \mathrm{Mg}\left(\mathrm{NO}_{3}\right)_{2}, \mathrm{Ca}\left(\mathrm{NO}_{3}\right)_{2}, \mathrm{Ni}\left(\mathrm{NO}_{3}\right)_{2}$ and $\mathrm{Cu}\left(\mathrm{NO}_{3}\right)_{2}$, after soaking $50 \mathrm{mg}$ of a polycrystalline sample of 2 .

\begin{tabular}{ccccc}
\hline Time (min.) & Pyronin Y(\%) & Auramine O (\%) & Brilliant Green (\%) & Methylene Blue (\%) \\
\hline 1 & 77.24 & 80.25 & 76.38 & 79.94 \\
5 & 82.99 & 86.23 & 86.56 & 87.78 \\
15 & 90.68 & 96.32 & 92.34 & 92.34 \\
60 & 94.77 & 98.34 & 95.67 & 96.65 \\
360 & 96.95 & 98.79 & 97.76 & 99.12 \\
1440 & 98.67 & 99.36 & 98.77 & 99.43 \\
& & & & \\
\hline
\end{tabular}

${ }^{\text {a }}$ Dye uptake (in \%) extracted from the UV-vis measurements. 
Table S6. Selected data for the capture process of the metal salts, obtained from the ICP-MS analyses, ${ }^{\mathrm{a}, \mathrm{b}}$ for one single aqueous solution (mineral water) containing $10 \mathrm{ppm}$ of PY, AO, BG and MB and $1 \mathrm{ppm}$ of $\mathrm{Hg}\left(\mathrm{NO}_{3}\right)_{2}, \mathrm{~Pb}\left(\mathrm{NO}_{3}\right)_{2}, \mathrm{TlNO}_{3}, \mathrm{NaNO}_{3}, \mathrm{KNO}_{3}, \mathrm{Mg}\left(\mathrm{NO}_{3}\right)_{2}, \mathrm{Ca}\left(\mathrm{NO}_{3}\right)_{2}, \mathrm{Ni}\left(\mathrm{NO}_{3}\right)_{2}$ and $\mathrm{Cu}\left(\mathrm{NO}_{3}\right)_{2}$, after soaking $50 \mathrm{mg}$ of a polycrystalline sample of 2 .

\begin{tabular}{|c|c|c|c|c|c|c|c|c|c|}
\hline $\begin{array}{l}\text { Time } \\
\text { (min.) }\end{array}$ & $H g^{2+}$ & $P b^{2+}$ & $T l^{+}$ & $\mathrm{Na}^{+}$ & $K^{+}$ & $M g^{2+}$ & $\mathrm{Ca}^{2+}$ & $N i^{2+}$ & $\mathrm{Cu}^{2+}$ \\
\hline 0 & 1012 & 1032 & 1032 & 1002 & 998 & 1008 & 1003 & 993 & 1031 \\
\hline 1 & 834 & 774 & 979 & 972 & 987 & 994 & 982 & 1013 & 1021 \\
\hline 5 & 374 & 325 & 967 & 987 & 998 & 979 & 999 & 987 & 1019 \\
\hline 10 & 211 & 179 & 912 & 998 & 998 & 951 & 973 & 977 & 1022 \\
\hline 15 & 126 & 95.4 & 854 & 1011 & 986 & 1023 & 993 & 953 & 986 \\
\hline 30 & 16.3 & 15.8 & 551 & 987 & 987 & 990 & 987 & 954 & 973 \\
\hline 45 & 14.9 & 12.7 & 478 & 998 & 982 & 993 & 998 & 962 & 995 \\
\hline 60 & 9.82 & 8.23 & 408 & 1011 & 999 & 1013 & 996 & 961 & 1005 \\
\hline 90 & 6.02 & 6.12 & 249 & 998 & 1002 & 987 & 990 & 955 & 985 \\
\hline 120 & 5.99 & 4.89 & 123 & 1011 & 992 & 998 & 989 & 961 & 975 \\
\hline 150 & 5.13 & 4.56 & 55.1 & 987 & 998 & 1011 & 998 & 958 & 986 \\
\hline 180 & 4.77 & 4.02 & 38.9 & 988 & 989 & 987 & 988 & 961 & 994 \\
\hline 210 & 4.72 & 4.21 & 13.3 & 1013 & 991 & 998 & 1013 & 957 & 999 \\
\hline 240 & 4.45 & 4.17 & 6.24 & 1020 & 989 & 1011 & 1020 & 959 & 985 \\
\hline 270 & 4.39 & 4.20 & 6.17 & 1004 & 991 & 998 & 1004 & 948 & 975 \\
\hline 300 & 4.37 & 4.32 & 6.29 & 990 & 1007 & 1011 & 991 & 951 & 986 \\
\hline 330 & 4.07 & 4.29 & 6.09 & 987 & 981 & 1002 & 992 & 962 & 999 \\
\hline 360 & 4.67 & 4.34 & 6.13 & 998 & 992 & 1011 & 1004 & 959 & 992 \\
\hline 720 & 4.12 & 4.21 & 6.23 & 998 & 991 & 989 & 990 & 947 & 981 \\
\hline 1440 & 4.43 & 4.08 & 6.34 & 1009 & 1011 & 1001 & 987 & 966 & 986 \\
\hline 2880 & 4.69 & 4.11 & 6.21 & 998 & 1002 & 996 & 979 & 957 & 990,2 \\
\hline
\end{tabular}

${ }^{a}$ Metal adsorption (wt. \%) extracted from the ICP-MS analyses. Results are given as $\mu$ g/L. ${ }^{\text {b }}$ L.D.: 0.012 $\mu \mathrm{g} / \mathrm{L}$. 
Table S7. Selected data $^{a}$ for the capture process of organic dyes, obtained from the UV-vis measurements, for one single aqueous solution (mineral water) containing $10 \mathrm{ppm}$ of PY, AO, BG and $\mathrm{MB}$ and $1 \mathrm{ppm}$ of $\mathrm{Hg}\left(\mathrm{NO}_{3}\right)_{2}, \mathrm{~Pb}\left(\mathrm{NO}_{3}\right)_{2}, \mathrm{TlNO}_{3}, \mathrm{NaNO}_{3}, \mathrm{KNO}_{3}, \mathrm{Mg}\left(\mathrm{NO}_{3}\right)_{2}, \mathrm{Ca}\left(\mathrm{NO}_{3}\right)_{2}, \mathrm{Ni}\left(\mathrm{NO}_{3}\right)_{2}$ and $\mathrm{Cu}\left(\mathrm{NO}_{3}\right)_{2}$, after soaking $50 \mathrm{mg}$ of a recycled polycrystalline sample of $\mathbf{2}$ (see main text).

\begin{tabular}{ccccc}
\hline Time (min.) & Pyronin Y(\%) & Auramine O (\%) & Brilliant Green (\%) & Methylene Blue (\%) \\
\hline 1 & 78.34 & 77.41 & 77.47 & 81.12 \\
5 & 83.47 & 84.11 & 84.21 & 88.52 \\
15 & 91.86 & 95.11 & 91.69 & 93.34 \\
60 & 94.89 & 96.41 & 94.99 & 97.41 \\
360 & 97.92 & 98.01 & 97.37 & 98.42 \\
1440 & 98.12 & 99.03 & 97.41 & 99.00 \\
& & & & \\
\hline
\end{tabular}

${ }^{\text {a }}$ Dye uptake (in \%) extracted from the UV-vis measurements. 
Table S8. Selected data for the capture process of the metal salts, obtained from the ICP-MS analyses, ${ }^{\mathrm{a}, \mathrm{b}}$ for one single aqueous solution (mineral water) containing $10 \mathrm{ppm}$ of $\mathrm{PY}, \mathrm{AO}, \mathrm{BG}$ and $\mathrm{MB}$ and $1 \mathrm{ppm}$ of $\mathrm{Hg}\left(\mathrm{NO}_{3}\right)_{2}, \mathrm{~Pb}\left(\mathrm{NO}_{3}\right)_{2}, \mathrm{TlNO}_{3}, \mathrm{NaNO}_{3}, \mathrm{KNO}_{3}, \mathrm{Mg}\left(\mathrm{NO}_{3}\right)_{2}, \mathrm{Ca}\left(\mathrm{NO}_{3}\right)_{2}, \mathrm{Ni}\left(\mathrm{NO}_{3}\right)_{2}$ and $\mathrm{Cu}\left(\mathrm{NO}_{3}\right)_{2}$, after soaking $50 \mathrm{mg}$ of a recycled polycrystalline sample of 2 (see main text).

\begin{tabular}{|c|c|c|c|c|c|c|c|c|c|}
\hline $\begin{array}{l}\text { Time } \\
\text { (min.) }\end{array}$ & $H g^{2+}$ & $P b^{2+}$ & $T l^{+}$ & $\mathrm{Na}^{+}$ & $K^{+}$ & $M g^{2+}$ & $\mathrm{Ca}^{2+}$ & $N i^{2+}$ & $\mathrm{Cu}^{2+}$ \\
\hline 0 & 1041 & 1011 & 1001 & 1032 & 1008 & 1012 & 1045 & 1010 & 1016 \\
\hline 1 & 869 & 850 & 956 & 987 & 1002 & 943 & 995 & 1033 & 1027 \\
\hline 5 & 389 & 377 & 923 & 982 & 992 & 951 & 990 & 1006 & 1027 \\
\hline 10 & 211 & 164 & 897 & 999 & 1013 & 957 & 1008 & 996 & 1008 \\
\hline 15 & 121 & 97 & 799 & 1002 & 990 & 997 & 1012 & 972 & 979 \\
\hline 30 & 18.2 & 19.8 & 569 & 992 & 989 & 992 & 1001 & 973 & 969 \\
\hline 45 & 14.3 & 14.8 & 508 & 1013 & 998 & 990 & 1024 & 981 & 986 \\
\hline 60 & 9.69 & 11.3 & 412 & 1020 & 948 & 989 & 1032 & 980 & 994 \\
\hline 90 & 6.29 & 7.29 & 361 & 1004 & 951 & 998 & 1014 & 974 & 978 \\
\hline 120 & 5.87 & 5.12 & 123 & 991 & 962 & 998 & 1000 & 980 & 971 \\
\hline 150 & 5.43 & 4.77 & 49.8 & 992 & 959 & 1011 & 1001 & 977 & 979 \\
\hline 180 & 5.12 & 4.53 & 32.4 & 990 & 941 & 987 & 999 & 980 & 985 \\
\hline 210 & 4.96 & 4.67 & 11.8 & 989 & 958 & 998 & 997 & 976 & 989 \\
\hline 240 & 4.49 & 4.48 & 6.41 & 998 & 966 & 1011 & 1007 & 978 & 978 \\
\hline 270 & 4.11 & 4.49 & 5.99 & 988 & 950 & 998 & 996 & 966 & 971 \\
\hline 300 & 4.12 & 4.53 & 6.04 & 1013 & 943 & 1011 & 1024 & 970 & 979 \\
\hline 330 & 4.07 & 4.45 & 6.08 & 961 & 951 & 950 & 967 & 981 & 989 \\
\hline 360 & 4.09 & 4.51 & 6.07 & 956 & 957 & 943 & 961 & 978 & 984 \\
\hline 720 & 4.05 & 4.46 & 6.11 & 947 & 997 & 951 & 951 & 965 & 975 \\
\hline 1440 & 4.06 & 4.39 & 5.98 & 951 & 982 & 957 & 956 & 985 & 979 \\
\hline 2880 & 3.98 & 4.41 & 5.77 & 954 & 999 & 961 & 959 & 976 & 982 \\
\hline
\end{tabular}

${ }^{a}$ Metal adsorption (wt. \%) extracted from the ICP-MS analyses. Results are given as $\mu$ g/L. ${ }^{\text {b }}$ L.D.: 0.012 $\mu \mathrm{g} / \mathrm{L}$. 
Table S9. Selected data $^{a}$ for the capture process of organic dyes, obtained from the UV-vis measurements, for one single aqueous solution (mineral water) containing $10 \mathrm{ppm}$ of PY, AO, BG and $\mathrm{MB}$ and 1 ppm of $\mathrm{Hg}\left(\mathrm{NO}_{3}\right)_{2}, \mathrm{~Pb}\left(\mathrm{NO}_{3}\right)_{2}, \mathrm{TlNO}_{3}, \mathrm{NaNO}_{3}, \mathrm{KNO}_{3}, \mathrm{Mg}\left(\mathrm{NO}_{3}\right)_{2}, \mathrm{Ca}\left(\mathrm{NO}_{3}\right)_{2}, \mathrm{Ni}\left(\mathrm{NO}_{3}\right)_{2}$ and $\mathrm{Cu}\left(\mathrm{NO}_{3}\right)_{2}$, after soaking $50 \mathrm{mg}$ of a polycrystalline mixture of $\mathbf{1 a}(25 \mathrm{mg})$ and $\mathbf{1 b}(25 \mathrm{mg})$.

\begin{tabular}{ccccc}
\hline Time (min.) & Pyronin $(\%)$ & Auramine O (\%) & Brilliant Green (\%) & Methylene Blue (\%) \\
\hline 1 & 61.12 & 62.32 & 63.51 & 59.44 \\
5 & 64.00 & 68.02 & 66.89 & 68.72 \\
15 & 71.43 & 75.12 & 74.34 & 73.84 \\
60 & 76.12 & 76.99 & 78.31 & 79.87 \\
360 & 77.89 & 77.12 & 81.54 & 81.54 \\
1440 & 79.51 & 81.34 & 83.11 & 82.34 \\
& & & & \\
\hline
\end{tabular}

${ }^{\text {a }}$ Dye uptake (in \%) extracted from the UV-vis measurements. 
Table S10. Selected data for the capture process of the metal salts, obtained from the ICP-MS analyses, ${ }^{\mathrm{a}, \mathrm{b}}$ for one single aqueous solution (mineral water) containing $10 \mathrm{ppm}$ of $\mathrm{PY}, \mathrm{AO}, \mathrm{BG}$ and $\mathrm{MB}$ and $1 \mathrm{ppm}$ of $\mathrm{Hg}\left(\mathrm{NO}_{3}\right)_{2}, \mathrm{~Pb}\left(\mathrm{NO}_{3}\right)_{2}, \mathrm{TlNO}_{3}, \mathrm{NaNO}_{3}, \mathrm{KNO}_{3}, \mathrm{Mg}\left(\mathrm{NO}_{3}\right)_{2}, \mathrm{Ca}\left(\mathrm{NO}_{3}\right)_{2}, \mathrm{Ni}\left(\mathrm{NO}_{3}\right)_{2}$ and $\mathrm{Cu}\left(\mathrm{NO}_{3}\right)_{2}$, after soaking $50 \mathrm{mg}$ of a polycrystalline mixture of $\mathbf{1 a}(25 \mathrm{mg})$ and $\mathbf{1 b}(25 \mathrm{mg})$.

\begin{tabular}{|c|c|c|c|c|c|c|c|c|c|}
\hline $\begin{array}{l}\text { Time } \\
\text { (min.) }\end{array}$ & $H g^{2+}$ & $P b^{2+}$ & $T l^{+}$ & $\mathrm{Na}^{+}$ & $K^{+}$ & $M g^{2+}$ & $\mathrm{Ca}^{2+}$ & $\mathrm{Ni}^{2+}$ & $C u^{2+}$ \\
\hline 0 & 992 & 1021 & 1011 & 1028 & 1013 & 1021 & 1001 & 1032 & 1017 \\
\hline 1 & 898 & 912 & 999 & 1013 & 991 & 987 & 997 & 1029 & 1002 \\
\hline 5 & 412 & 469 & 987 & 998 & 1008 & 988 & 985 & 1026 & 1003 \\
\hline 10 & 252 & 289 & 934 & 970 & 982 & 1013 & 989 & 1016 & 998 \\
\hline 15 & 157 & 167 & 908 & 1043 & 1002 & 1020 & 997 & 991 & 970 \\
\hline 30 & 67.0 & 71.3 & 612 & 1009 & 996 & 1004 & 984 & 992 & 959 \\
\hline 45 & 31.0 & 34.3 & 554 & 1012 & 1007 & 990 & 1004 & 1000 & 977 \\
\hline 60 & 27.3 & 29.3 & 499 & 1033 & 1005 & 987 & 998 & 999 & 985 \\
\hline 90 & 24.3 & 28.9 & 451 & 1006 & 999 & 998 & 970 & 993 & 969 \\
\hline 120 & 21.4 & 26.4 & 167 & 1017 & 998 & 998 & 959 & 999 & 961 \\
\hline 150 & 17.8 & 21.34 & 89.1 & 1031 & 1007 & 1009 & 1000 & 996 & 970 \\
\hline 180 & 15.3 & 17.3 & 77.3 & 1006 & 997 & 998 & 999 & 999 & 976 \\
\hline 210 & 10.0 & 11.2 & 67.3 & 1017 & 1023 & 982 & 993 & 995 & 980 \\
\hline 240 & 10.0 & 10.4 & 52.8 & 1031 & 1030 & 999 & 999 & 997 & 969 \\
\hline 270 & 9.23 & 8.98 & 45.2 & 1017 & 1014 & 1002 & 1004 & 985 & 961 \\
\hline 300 & 8.02 & 7.12 & 27.5 & 1031 & 1000 & 992 & 991 & 989 & 970 \\
\hline 330 & 7.12 & 6.47 & 15.7 & 1022 & 1001 & 998 & 992 & 1000 & 980 \\
\hline 360 & 5.34 & 5.89 & 9.78 & 1031 & 1014 & 989 & 1004 & 997 & 975 \\
\hline 720 & 5.17 & 5.67 & 8.45 & 1008 & 999 & 991 & 975 & 984 & 965 \\
\hline 1440 & 5.08 & 5.56 & 8.12 & 1021 & 996 & 989 & 965 & 1004 & 970 \\
\hline 2880 & 5.12 & 5.51 & 7.89 & 1015 & 988 & 991 & 970 & 995 & 973 \\
\hline
\end{tabular}

${ }^{a}$ Metal adsorption (wt. \%) extracted from the ICP-MS analyses. Results are given as $\mu$ g/L. ${ }^{\text {b }}$ L.D.: 0.012 $\mu \mathrm{g} / \mathrm{L}$. 


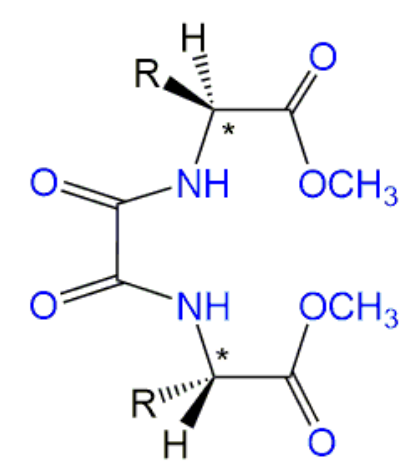

$\mathrm{H}_{2} \mathrm{Me}_{2} \mathrm{~L}$

$$
\begin{array}{ll}
\mathrm{R}=-\mathrm{CH}_{2} \mathrm{CH}_{2} \mathrm{SCH}_{3} & \mathrm{H}_{2} \mathrm{Me}_{2}-(\mathrm{S}, \mathrm{S}) \text {-methox } \\
\mathrm{R}=-\mathrm{CH}_{2} \mathrm{OH} & \mathrm{H}_{2} \mathrm{Me}_{2}-(\mathrm{S}, \mathrm{S}) \text {-serimox }
\end{array}
$$

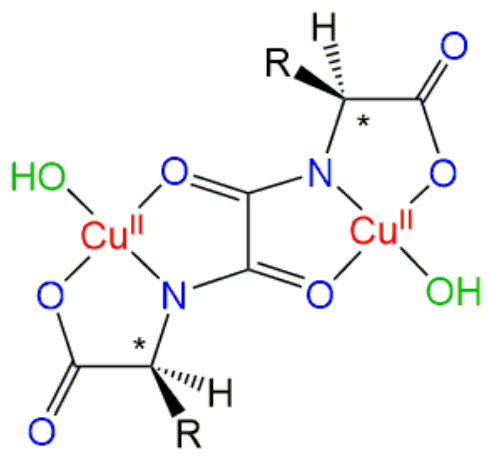

$\left[\mathrm{Cu}_{2}{ }_{2} \mathrm{~L}\left(\mathrm{OH}_{2}\right)\right]^{2-}$

$$
\begin{aligned}
& \left\{\mathrm{Cu}_{2}[(\mathrm{~S}, \mathrm{~S}) \text {-methox }](\mathrm{OH})_{2}\right\}^{2-} \\
& \left\{\mathrm{Cu}_{2}[(\mathrm{~S}, \mathrm{~S}) \text {-serimox }](\mathrm{OH})_{2}\right\}^{2-}
\end{aligned}
$$

Scheme S1. Chemical structures of the chiral bis(amino acid)oxalamide ligands (left), highlighting the potential coordination sites and chiral centers $\left(^{*}\right)$ and the corresponding dianionic bis(hydroxo) dicopper(II) complexes (right). 


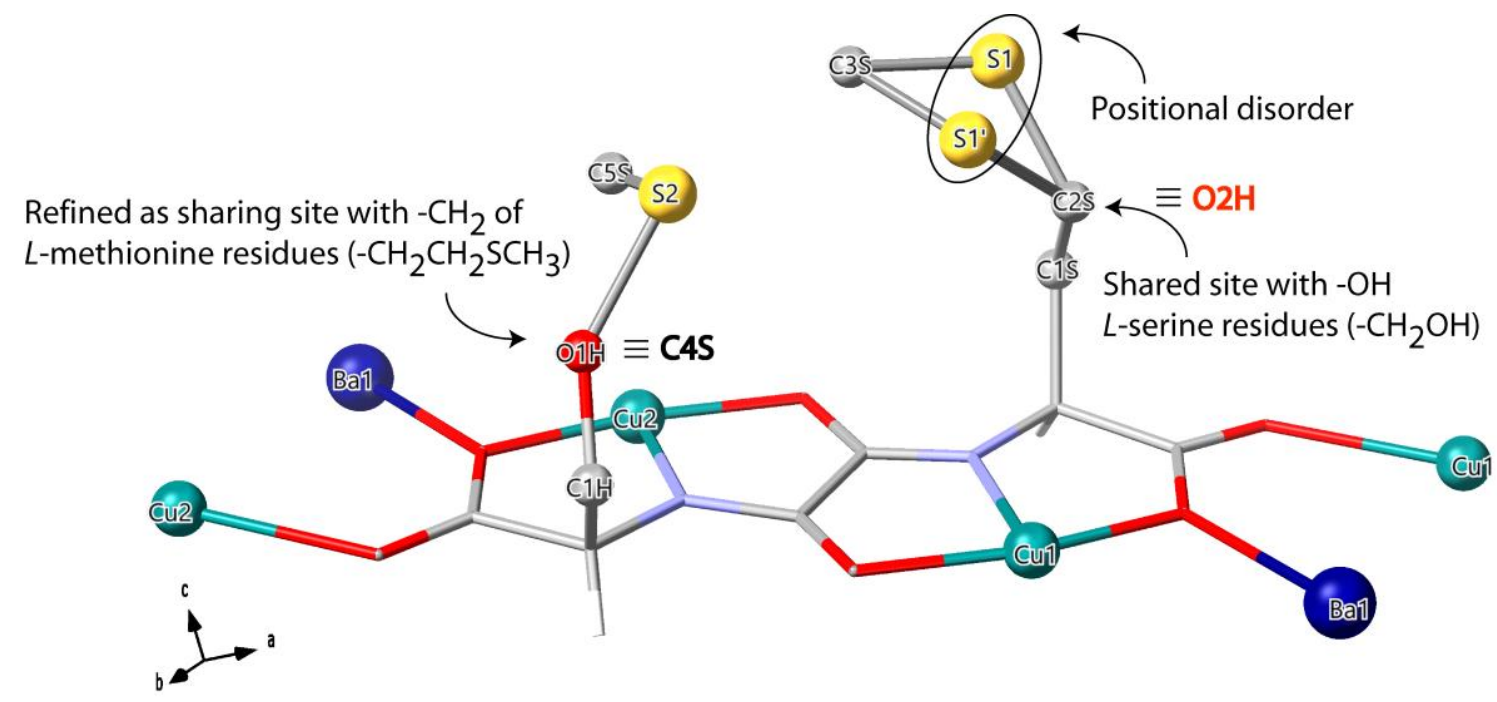

Scheme S2. Schematic representation of the 'quasi realistic' crystallographic model otherwise applied for dicopper(II) complexes in sample 2' and presented as alternative way to solve the crystal structure (in 2b'_model2 CIF). 

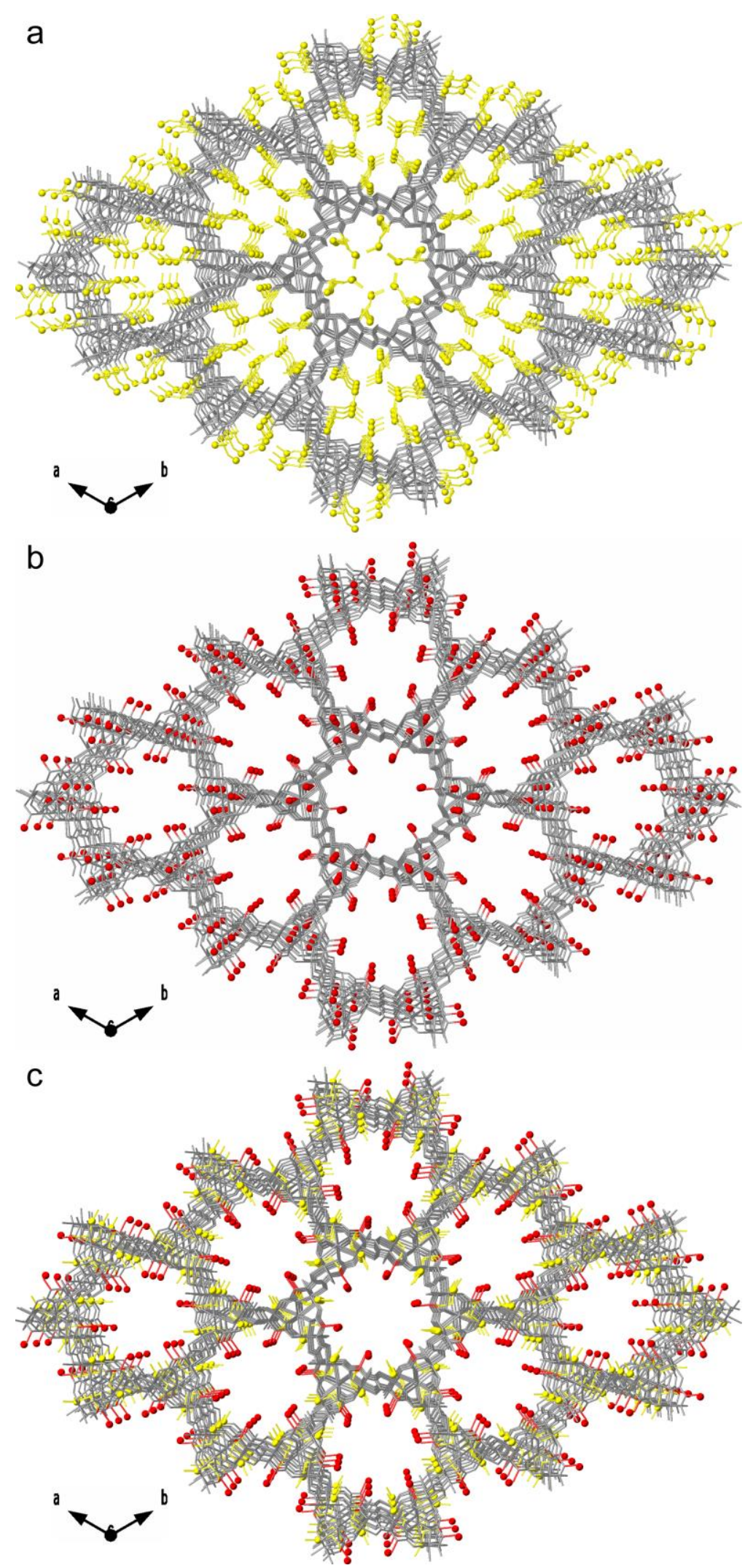

Figure S1. Perspective views of the porous structures of $\left\{\mathrm{Ca}^{\mathrm{II}} \mathrm{Cu}^{\mathrm{II}} 6[(S, S) \text {-methox }]_{3}(\mathrm{OH})_{2}\left(\mathrm{H}_{2} \mathrm{O}\right)\right\} \cdot 16 \mathrm{H}_{2} \mathrm{O}$ 1a (a), $\left\{\mathrm{Ca}^{\mathrm{II}} \mathrm{Cu}_{6}{ }_{6}[(S, S) \text {-serimox }]_{3}(\mathrm{OH})_{2}\left(\mathrm{H}_{2} \mathrm{O}\right)\right\} \cdot 39 \mathrm{H}_{2} \mathrm{O} \mathbf{1 b}$ (b) and the MTV-MOF 2 (c) along the $c$ axis (the crystallization water molecules are omitted for clarity). Ligands and metal atoms from the network are depicted as gray stick with the exception of the $L$-serine $\left(-\mathrm{CH}_{2} \mathrm{OH}\right)$ and $L$-methionine ($\mathrm{CH}_{2} \mathrm{CH}_{2} \mathrm{SCH}_{3}$ ) residues, which are represented as red and yellow sticks, respectively. Oxygen and Sulphur atoms from the residues are shown as red and yellow spheres, respectively. 


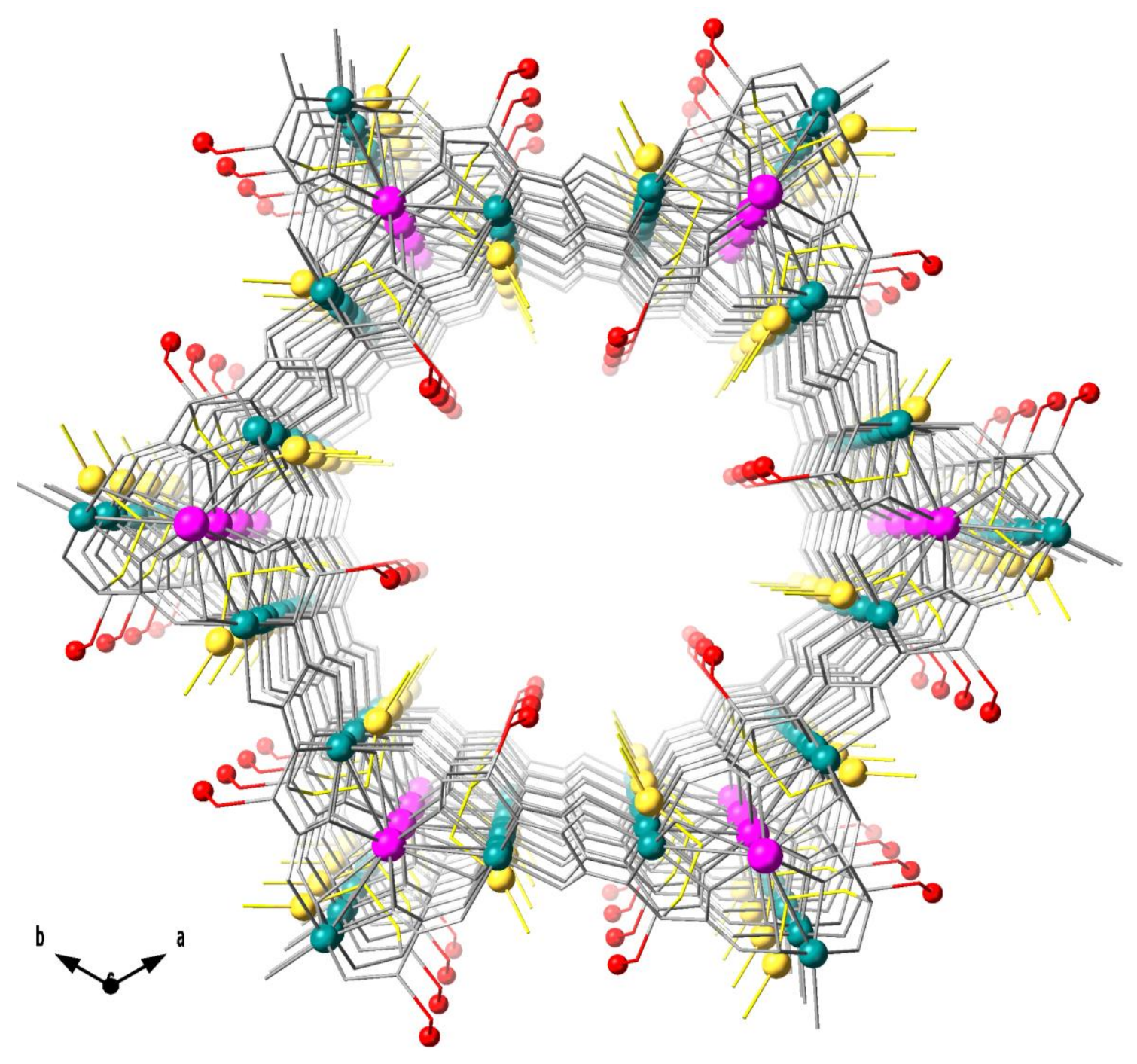

Figure S2. Perspective view of a single channel for the porous structure of the MTV-MOF 2 along the $c$ axis (the crystallization water molecules are omitted for clarity). Ligands from the network are depicted as gray stick with the exception of the $L$-serine $\left(-\mathrm{CH}_{2} \mathrm{OH}\right)$ and $L$-methionine $\left(-\mathrm{CH}_{2} \mathrm{CH}_{2} \mathrm{SCH}_{3}\right)$ residues, which are represented as red and yellow sticks, respectively. Copper(II) and calcium(II) ions from the network are represented as cyan and purple spheres, respectively. Oxygen and sulphur atoms from the residues are shown as red and yellow spheres, respectively. 


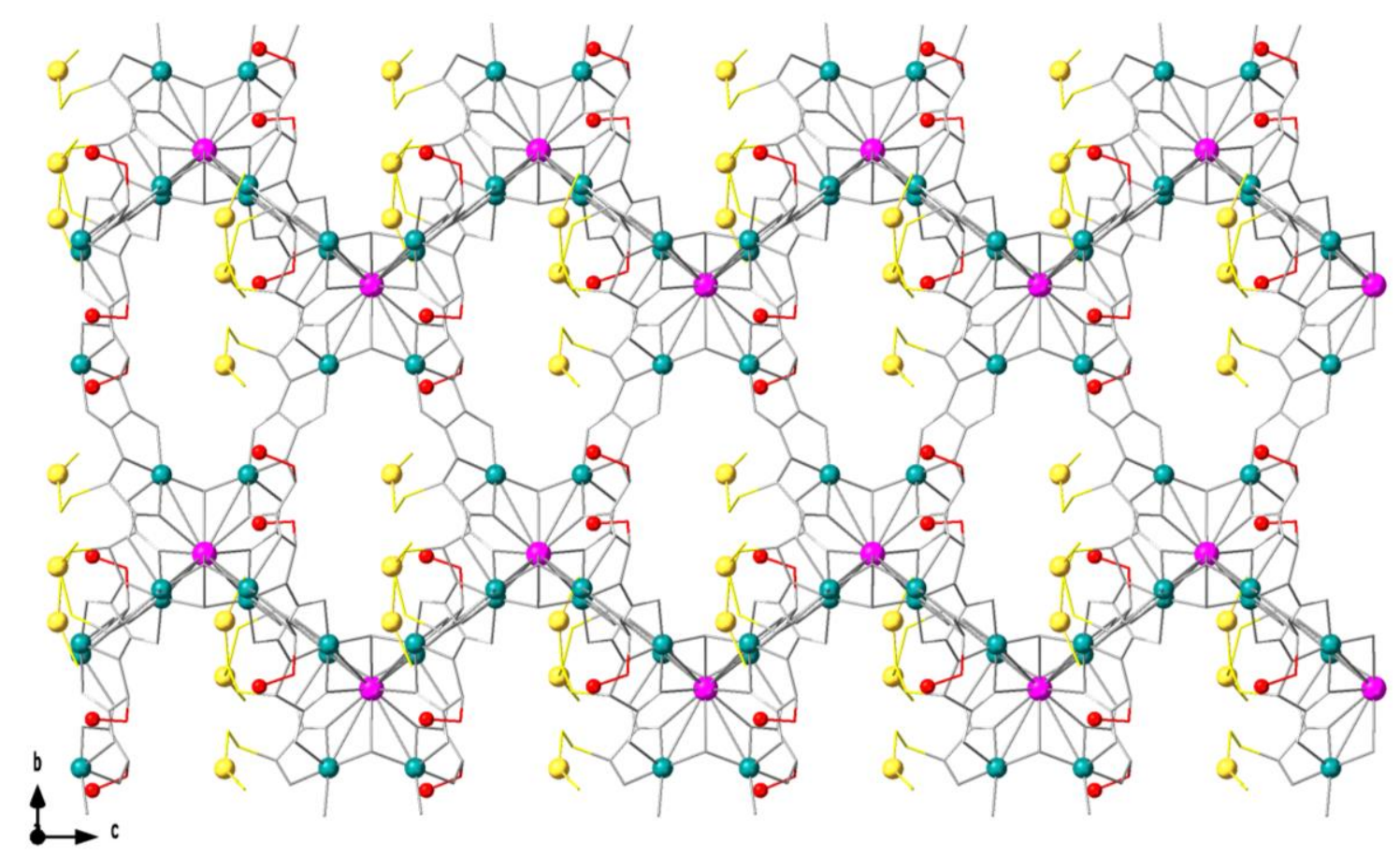

Figure S3. View of a single channel for the porous structure of the MTV-MOF 2 along the $a$ axis (the crystallization water molecules are omitted for clarity). Ligands from the network are depicted as gray stick with the exception of the $L$-serine $\left(-\mathrm{CH}_{2} \mathrm{OH}\right)$ and $L$-methionine $\left(-\mathrm{CH}_{2} \mathrm{CH}_{2} \mathrm{SCH}_{3}\right)$ residues, which are represented as red and yellow sticks, respectively. Copper(II) and calcium(II) ions from the network are represented as cyan and purple spheres, respectively. Oxygen and sulphur atoms from the residues are shown as red and yellow spheres, respectively. 


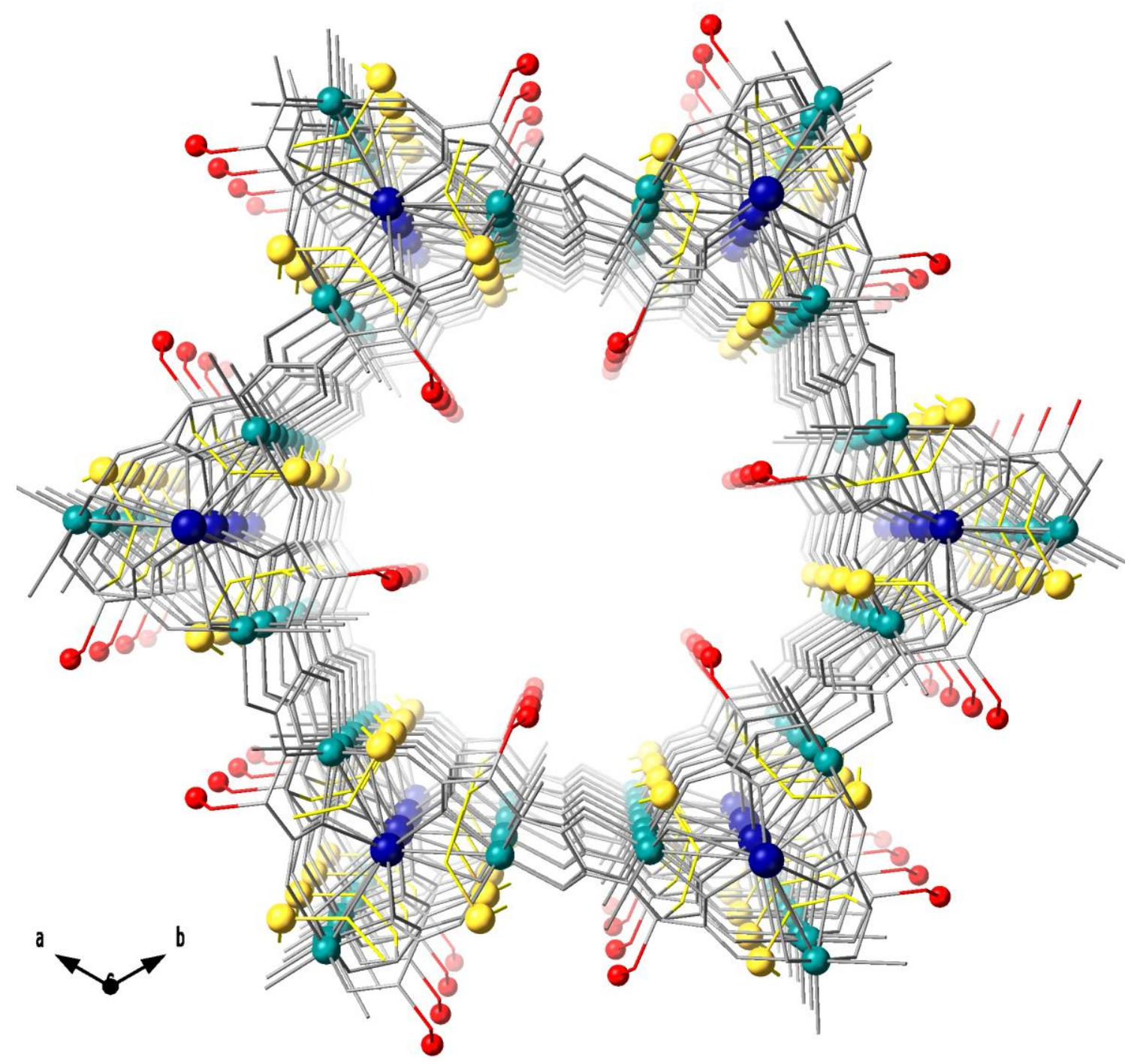

Figure S4. Perspective view of a single channel of the porous structure of the MTV-MOF 2' along the $c$ axis (the crystallization water molecules are omitted for clarity). Ligands from the network are depicted as gray stick with the exception of the $L$-serine $\left(-\mathrm{CH}_{2} \mathrm{OH}\right)$ and $L$-methionine $\left(-\mathrm{CH}_{2} \mathrm{CH}_{2} \mathrm{SCH}_{3}\right)$ residues, which are represented as red and yellow sticks, respectively. Copper(II) and barium(II) ions from the network are represented as cyan and blue spheres, respectively. Oxygen and sulphur atoms from the residues are shown as red and yellow spheres, respectively. 


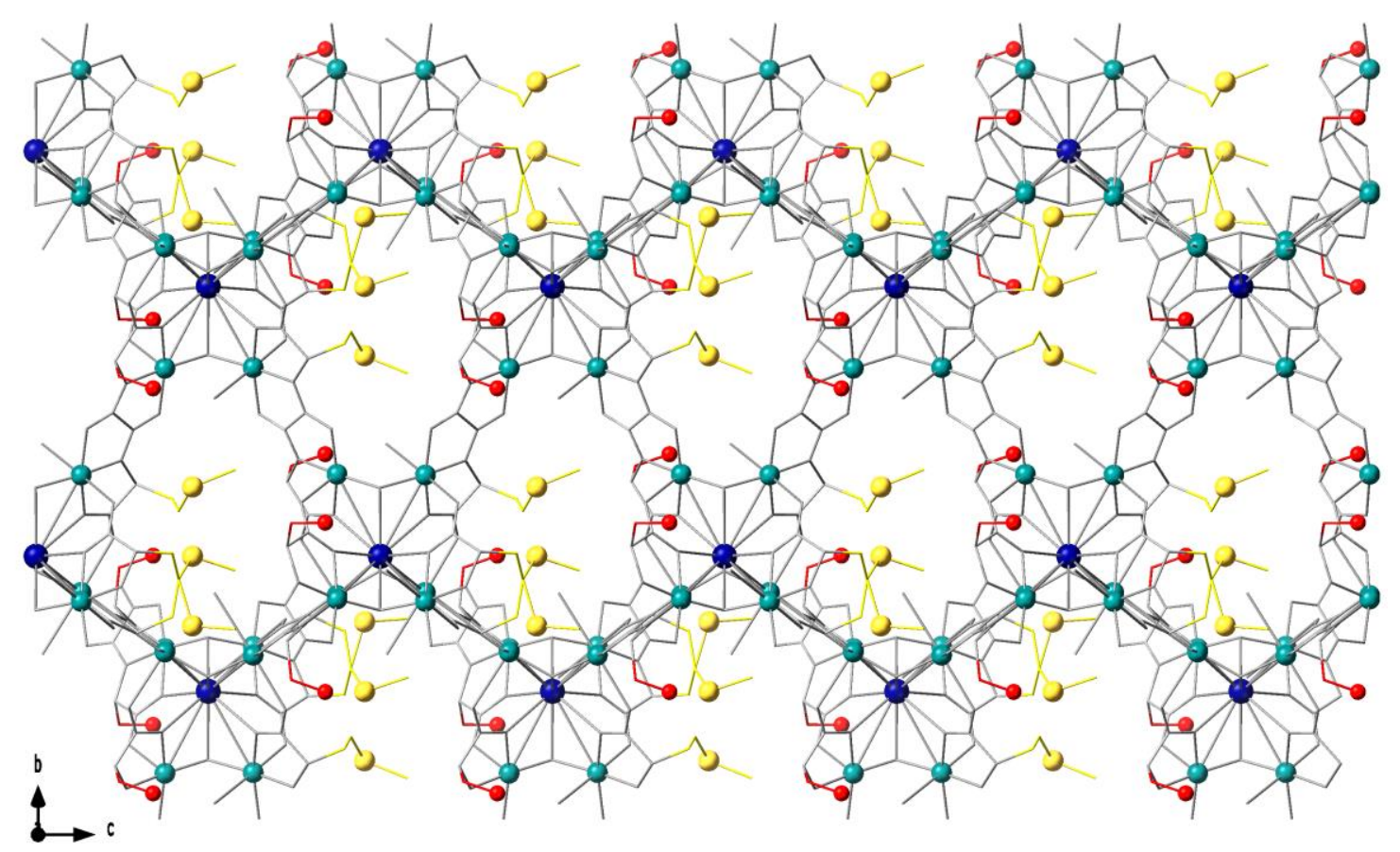

Figure S5. View of a single channel of the porous structure of the MTV-MOF 2' along the $a$ axis (the crystallization water molecules are omitted for clarity). Ligands from the network are depicted as gray stick with the exception of the $L$-serine $\left(-\mathrm{CH}_{2} \mathrm{OH}\right)$ and $L$-methionine $\left(-\mathrm{CH}_{2} \mathrm{CH}_{2} \mathrm{SCH}_{3}\right)$ residues, which are represented as red and yellow sticks, respectively. Copper(II) and barium(II) ions from the network are represented as cyan and blue spheres, respectively. Oxygen and sulphur atoms from the residues are shown as red and yellow spheres, respectively. 

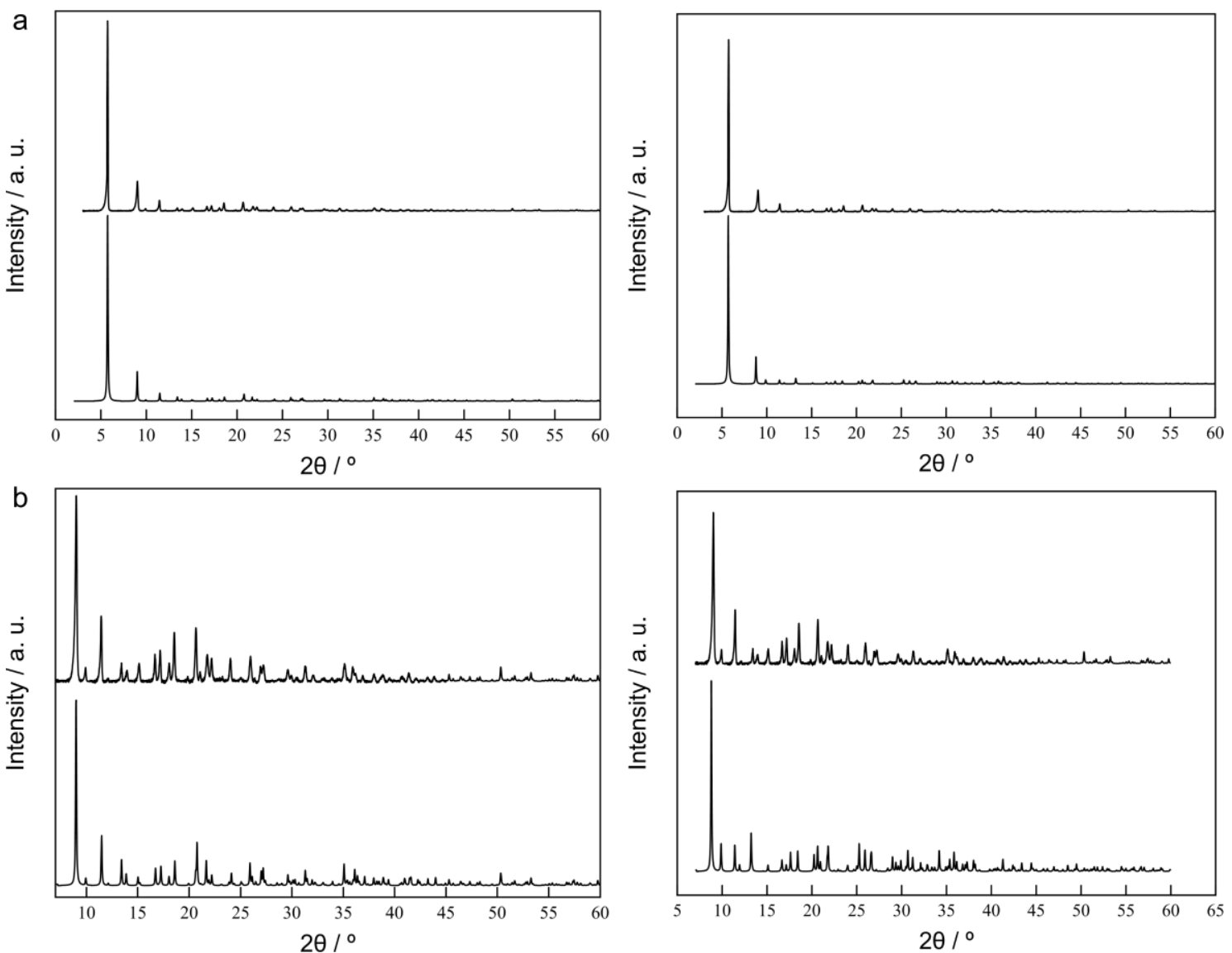

Figure S6. Theoretical (bottom) and experimental (top) PXRD patterns of 2 (left) and 2' (right) in the $2.0-60.0^{\circ}$ (a) and $7.0-60.0^{\circ}$ (b) $2 \theta$ range measured at room temperature. 


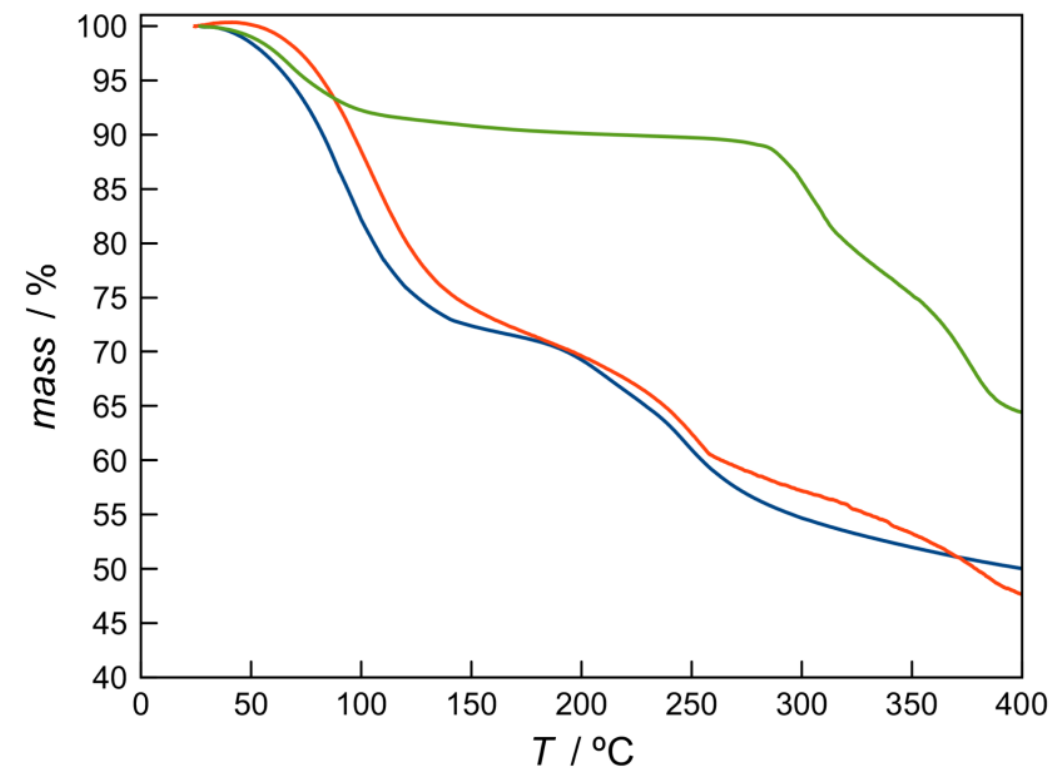

Figure S7. Thermo-Gravimetric Analysis (TGA) of 2 (blue), 2' (red) and (MB)· $\mathbf{H g C l}_{2} @ 2$ (green) under dry $\mathrm{N}_{2}$ atmosphere. 


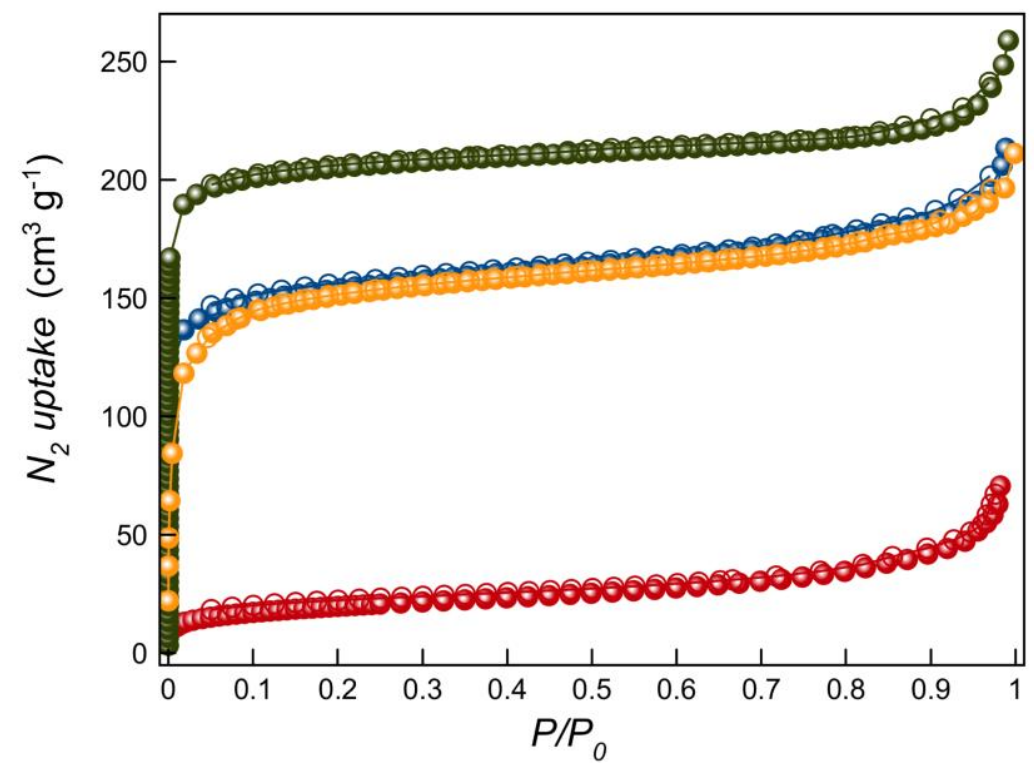

Figure S8. $\mathrm{N}_{2}(77 \mathrm{~K})$ adsorption isotherms for the activated compounds 1a (red), $\mathbf{1 b}$ (green), $\mathbf{2}$ (blue) and 2' (orange). Filled and empty symbols indicate the adsorption and desorption isotherms, respectively. The samples were activated at $70{ }^{\circ} \mathrm{C}$ under reduced pressure for $16 \mathrm{~h}$ prior to carry out the sorption measurements. 

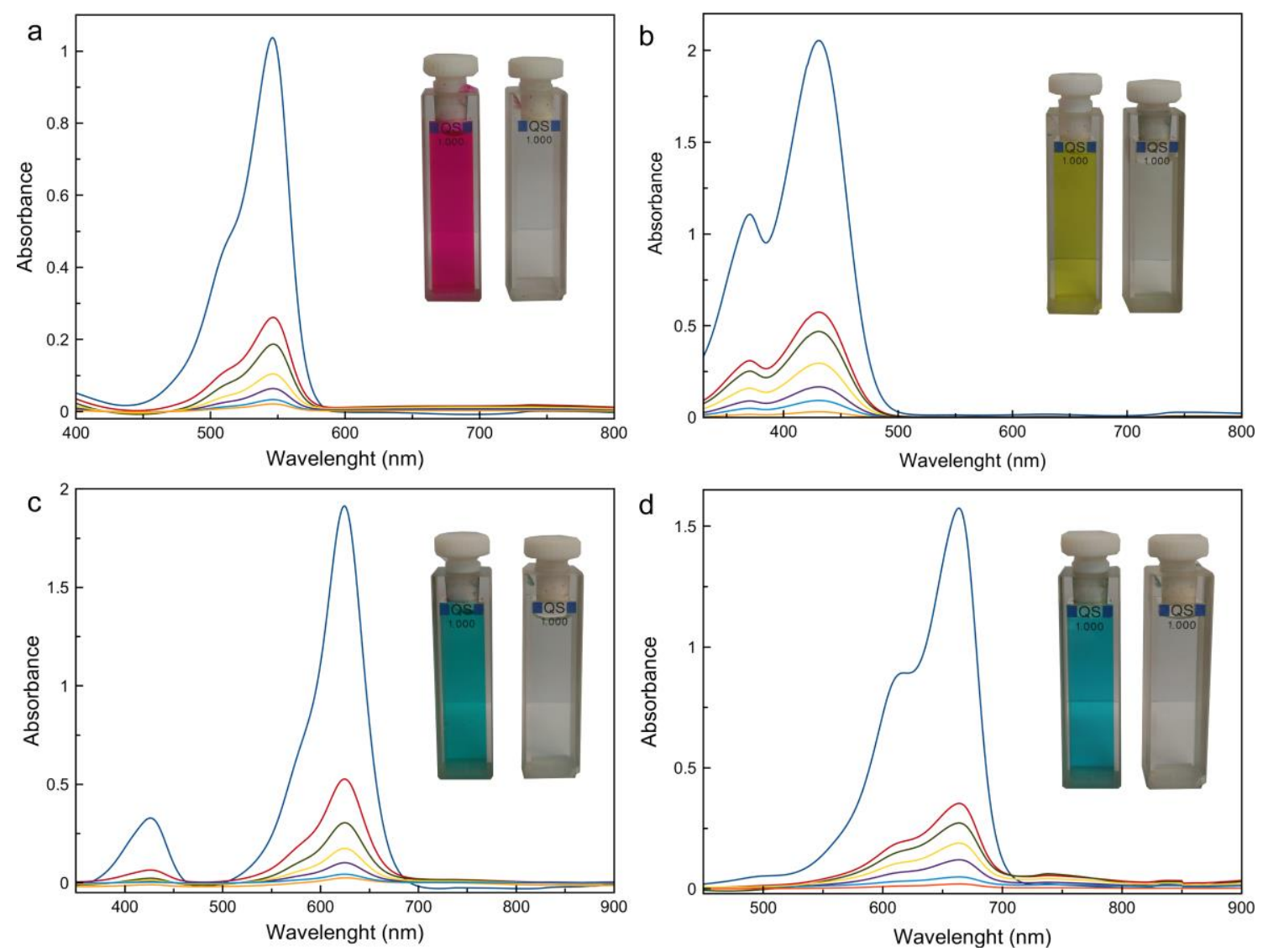

Figure S9. Evolution with time of the UV-Vis absorption spectra of $10 \mathrm{ppm}$ solutions of Pyronin Y (a), Auramine $\mathrm{O}(\mathrm{b})$, Brilliant green (c) and Methylene blue (d) in distilled water in the presence of $50 \mathrm{mg}$ of a polycrystalline sample of 2. Blue: $t=0$; Red: $t=1 \mathrm{~min}$; Green: $t=5 \mathrm{~min}$; Yellow: $t=15$ min.; Purple: $t=30$ min.; Light Blue: $t=60 \mathrm{~min}$; Orange: $t=24 \mathrm{~h}$. The photographs show the colours of the solutions before (left) and after $24 \mathrm{~h}$. (right) of exposure of the corresponding dye solution with MOF 2. 


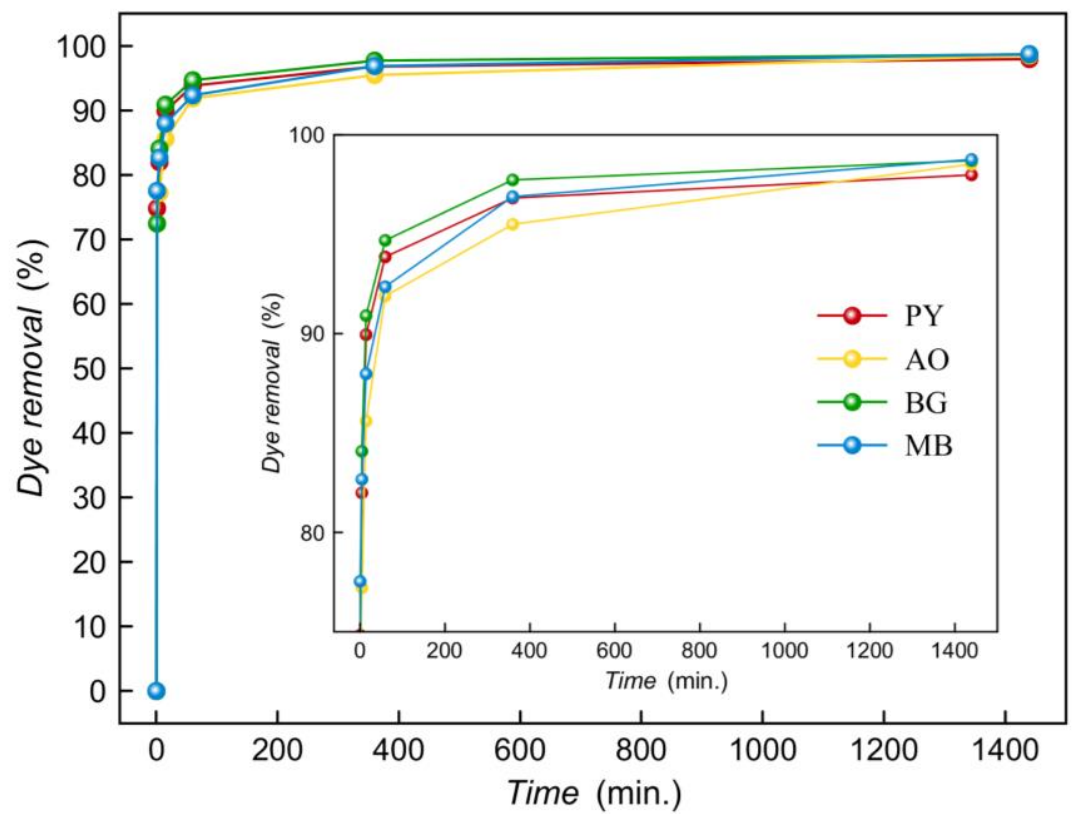

Figure S10. Kinetic profile of the independent removal of Pyronin Y (red), Auramine $\mathrm{O}$ (yellow), Brilliant green (green) and Methylene blue (blue) from distilled mineral water by 2 . The inset shows a zoom for the sake of clarity. Data for the preparation of this picture are collected in Table S2 (see also Figure S9). 


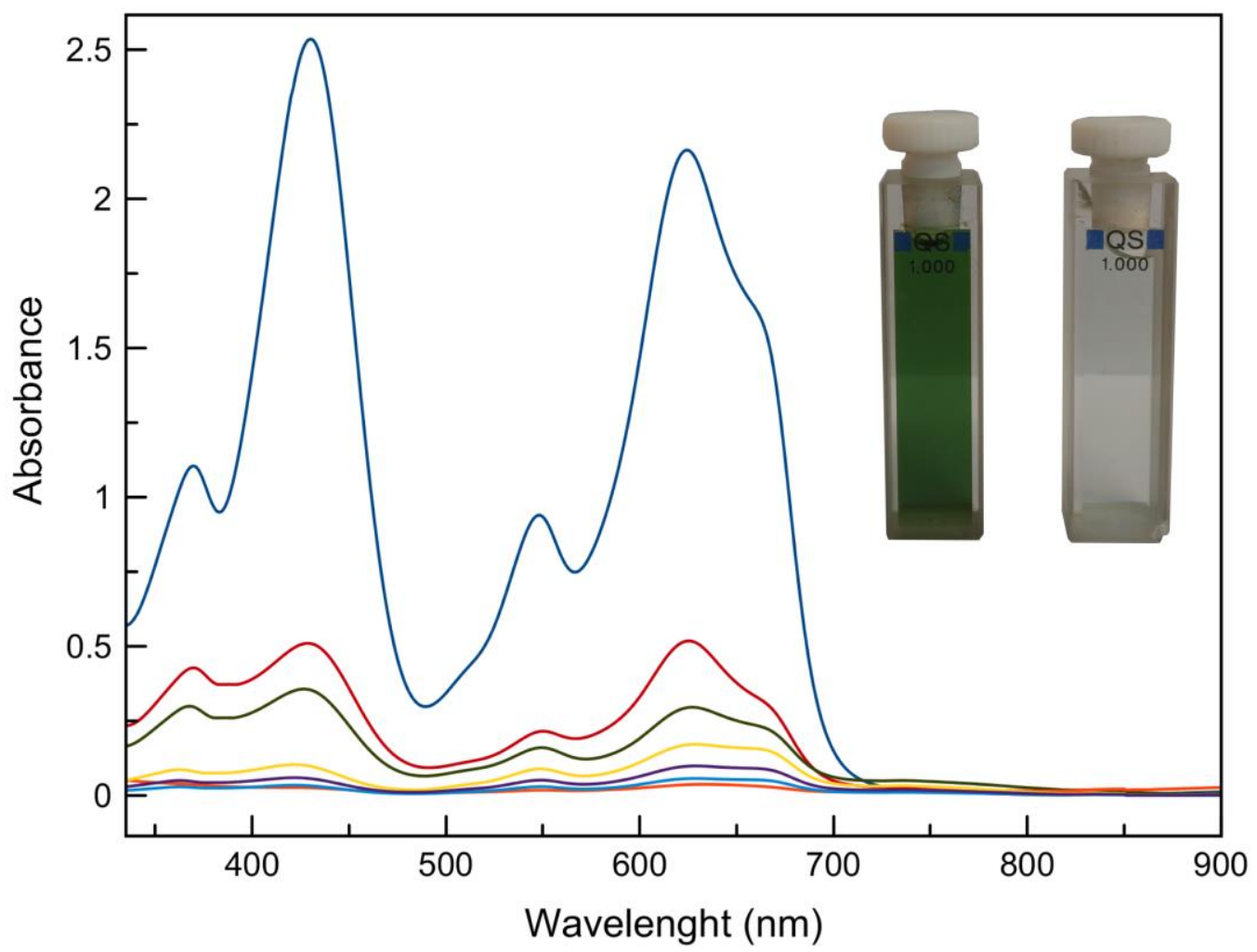

Figure S11. Kinetic profile of the UV-Vis absorption spectra of a multi-dye solution containing $10 \mathrm{ppm}$ of PY, AO, BG and MB in mineral water in the presence of $50 \mathrm{mg}$ of a sample of 1. Blue: $t=0$; Red: $t=$ 1 min.; Green: $t=5$ min.; Yellow: $t=15$ min.; Purple: $t=60 \mathrm{~min}$.; Light blue: $t=6 \mathrm{~h}$.; Orange: $t=24 \mathrm{~h}$. The photographs show the colors of the solutions before (left) and after $24 \mathrm{~h}$. (right) of exposure of the multi-dye solution with MOF 2. 


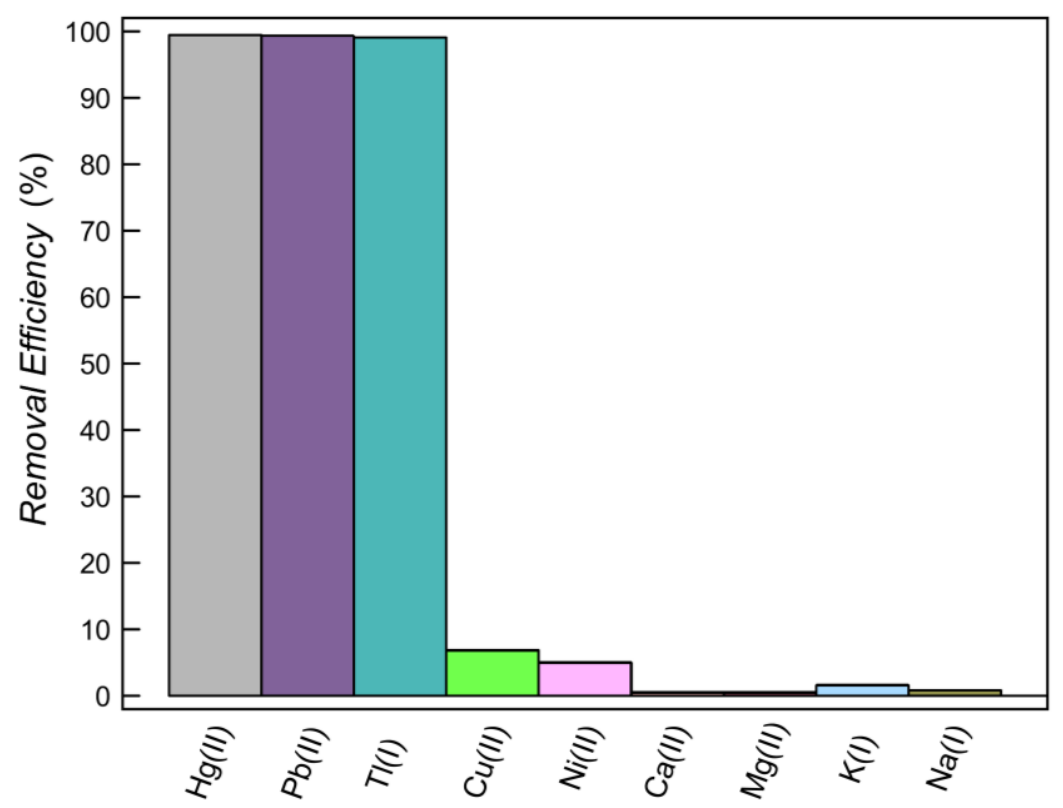

Figure S12. Maximum recovery (after 48 h.) of $\mathrm{Hg}(\mathrm{II}), \mathrm{Pb}(\mathrm{II}), \mathrm{Tl}(\mathrm{I})$, $\mathrm{Cu}(\mathrm{II}), \mathrm{Ni}(\mathrm{II}), \mathrm{Ca}(\mathrm{II}), \mathrm{Mg}(\mathrm{II}), \mathrm{K}(\mathrm{I})$ and $\mathrm{Na}(\mathrm{I})$ by MTV-MOF 2 in an aqueous 1 ppm solution of $\mathrm{Hg}\left(\mathrm{NO}_{3}\right)_{2}, \mathrm{~Pb}\left(\mathrm{NO}_{3}\right)_{2}, \mathrm{TlNO}_{3}, \mathrm{NaNO}_{3}, \mathrm{KNO}_{3}$, $\mathrm{Mg}\left(\mathrm{NO}_{3}\right)_{2}, \mathrm{Ca}\left(\mathrm{NO}_{3}\right)_{2}, \mathrm{Ni}\left(\mathrm{NO}_{3}\right)_{2}$ and $\mathrm{Cu}\left(\mathrm{NO}_{3}\right)_{2}$ after soaking $50 \mathrm{mg}$ of 2 (data collected in Table S4). 


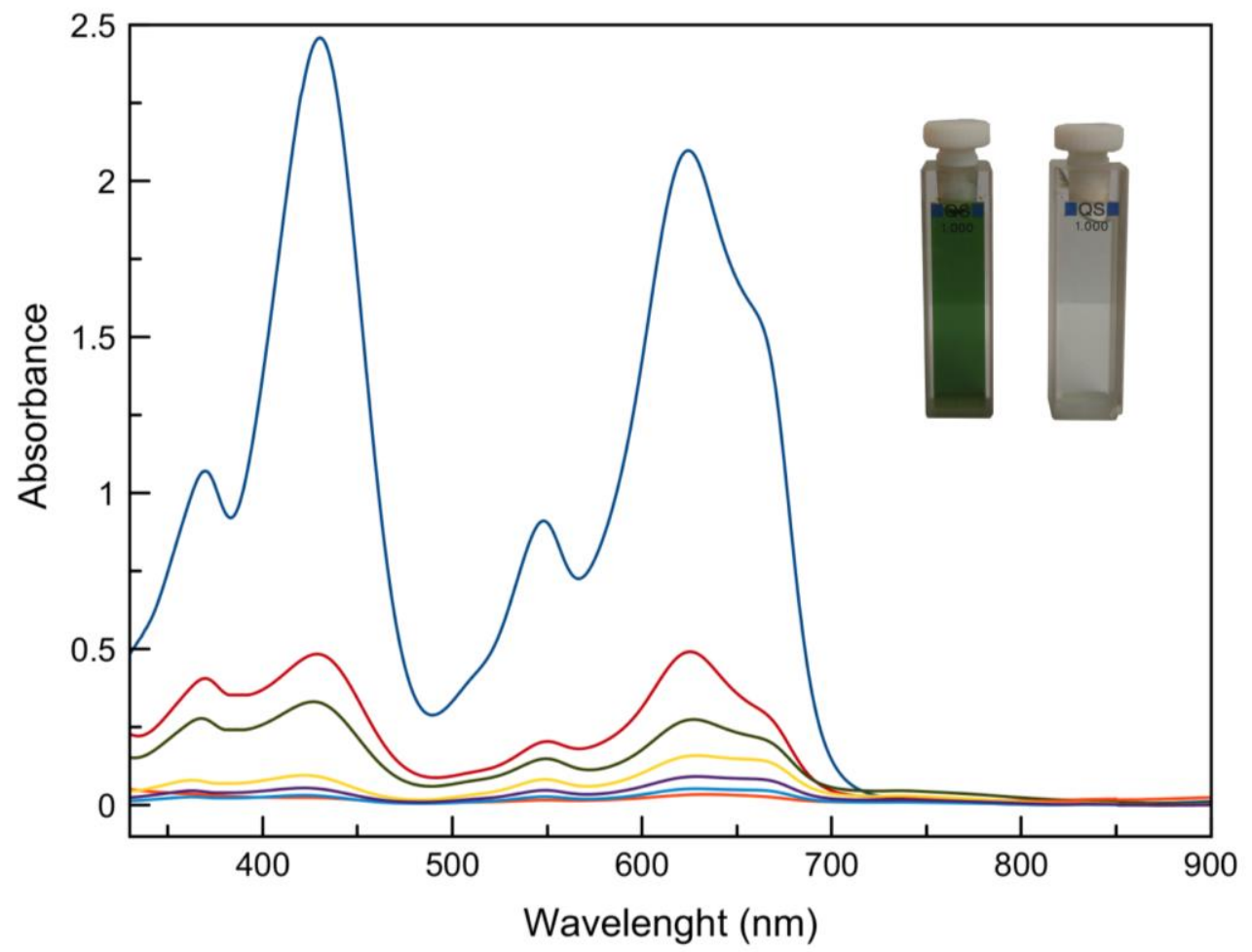

Figure S13. Kinetic profile of the UV-Vis absorption spectra of an aqueous solution (mineral water) containing $10 \mathrm{ppm}$ of $\mathrm{PY}, \mathrm{AO}, \mathrm{BG}$ and $\mathrm{MB}$ and $1 \mathrm{ppm}$ of $\mathrm{Hg}\left(\mathrm{NO}_{3}\right)_{2}$, $\mathrm{Pb}\left(\mathrm{NO}_{3}\right)_{2}, \mathrm{TlNO}_{3}, \mathrm{NaNO}_{3}, \mathrm{KNO}_{3}, \mathrm{Mg}\left(\mathrm{NO}_{3}\right)_{2}, \mathrm{Ca}\left(\mathrm{NO}_{3}\right)_{2}, \mathrm{Ni}\left(\mathrm{NO}_{3}\right)_{2}$ and $\mathrm{Cu}\left(\mathrm{NO}_{3}\right)_{2}$ by $50 \mathrm{mg}$ of 2. Blue: $t=0$; Red: $t=1$ min.; Green: $t=5$ min.; Yellow: $t=15$ min.; Purple: $t=60$ min.; Light blue: $t=6 \mathrm{~h}$; Orange: $t=24 \mathrm{~h}$. The photographs show the colors of the solutions before (left) and after $24 \mathrm{~h}$. (right) of exposure of the multi-contaminant solution with MOF 2. 


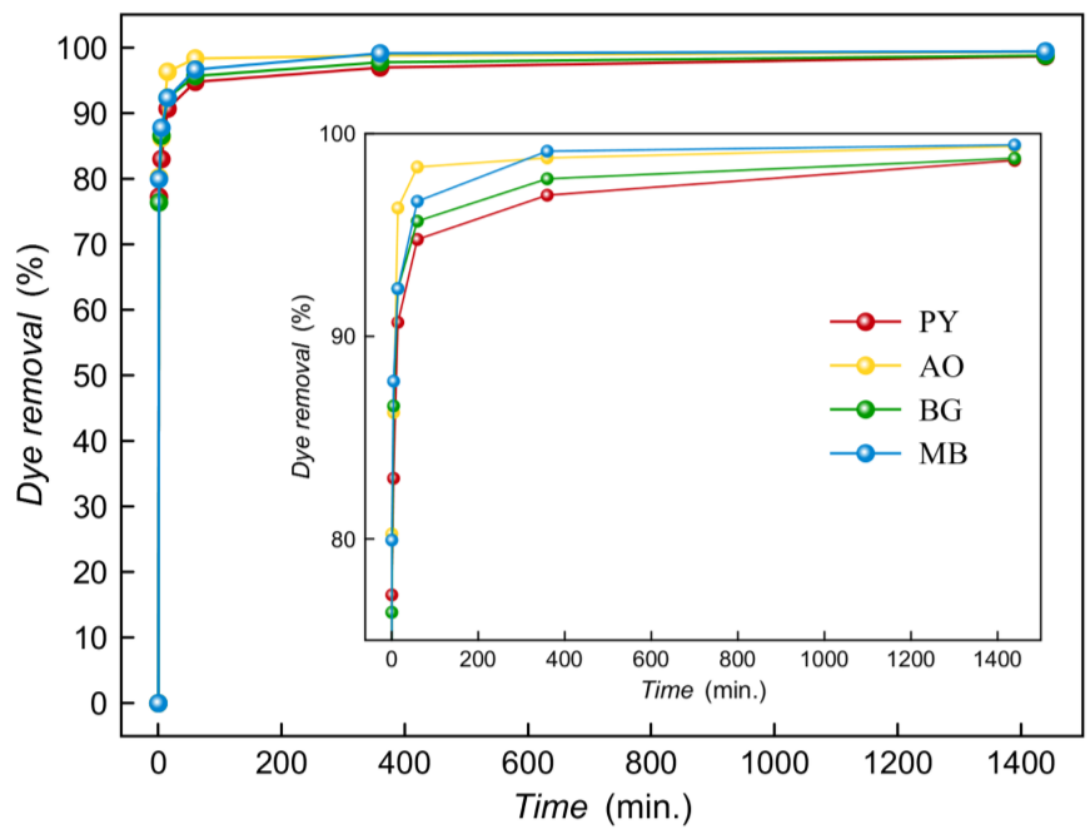

Figure S14. Kinetic profile of the removal of Pyronin Y (red), Auramine O (yellow), Brilliant green (green) and Methylene blue (blue) from an aqueous solution (mineral water) containing $10 \mathrm{ppm}$ of $\mathrm{PY}, \mathrm{AO}, \mathrm{BG}$ and $\mathrm{MB}$ and 1 ppm of $\mathrm{Hg}\left(\mathrm{NO}_{3}\right)_{2}, \mathrm{~Pb}\left(\mathrm{NO}_{3}\right)_{2}, \mathrm{TlNO}_{3}, \mathrm{NaNO}_{3}, \mathrm{KNO}_{3}, \mathrm{Mg}\left(\mathrm{NO}_{3}\right)_{2}, \mathrm{Ca}\left(\mathrm{NO}_{3}\right)_{2}$, $\mathrm{Ni}\left(\mathrm{NO}_{3}\right)_{2}$ and $\mathrm{Cu}\left(\mathrm{NO}_{3}\right)_{2}$ by $50 \mathrm{mg}$ of 2 . Data for the preparation of this picture are collected in Table S5 (see also Figure S13). 


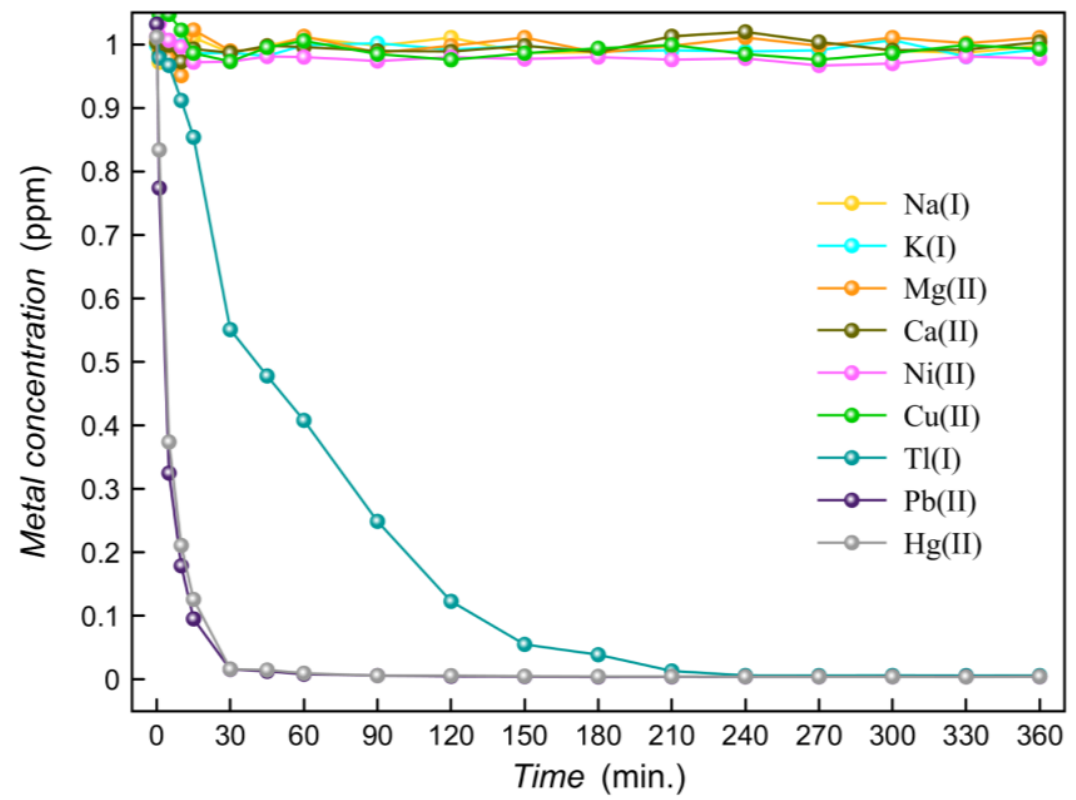

Figure S15. Kinetic profile of the metal capture by MTV-MOF 2 measured as the decrease of the different metal concentration with time after soaking $50 \mathrm{mg}$ of 2 in an aqueous solution (mineral water) containing $10 \mathrm{ppm}$ of PY, $\mathrm{AO}, \mathrm{BG}$ and $\mathrm{MB}$ and $1 \mathrm{ppm}$ of $\mathrm{Hg}\left(\mathrm{NO}_{3}\right)_{2}, \mathrm{~Pb}\left(\mathrm{NO}_{3}\right)_{2}, \mathrm{TlNO}_{3}, \mathrm{NaNO}_{3}, \mathrm{KNO}_{3}$, $\mathrm{Mg}\left(\mathrm{NO}_{3}\right)_{2}, \mathrm{Ca}\left(\mathrm{NO}_{3}\right)_{2}, \mathrm{Ni}\left(\mathrm{NO}_{3}\right)_{2}$ and $\mathrm{Cu}\left(\mathrm{NO}_{3}\right)_{2}$ in the 0-48 h. interval (data collected in Table S6). The graph only shows the 0-360 min. interval. 


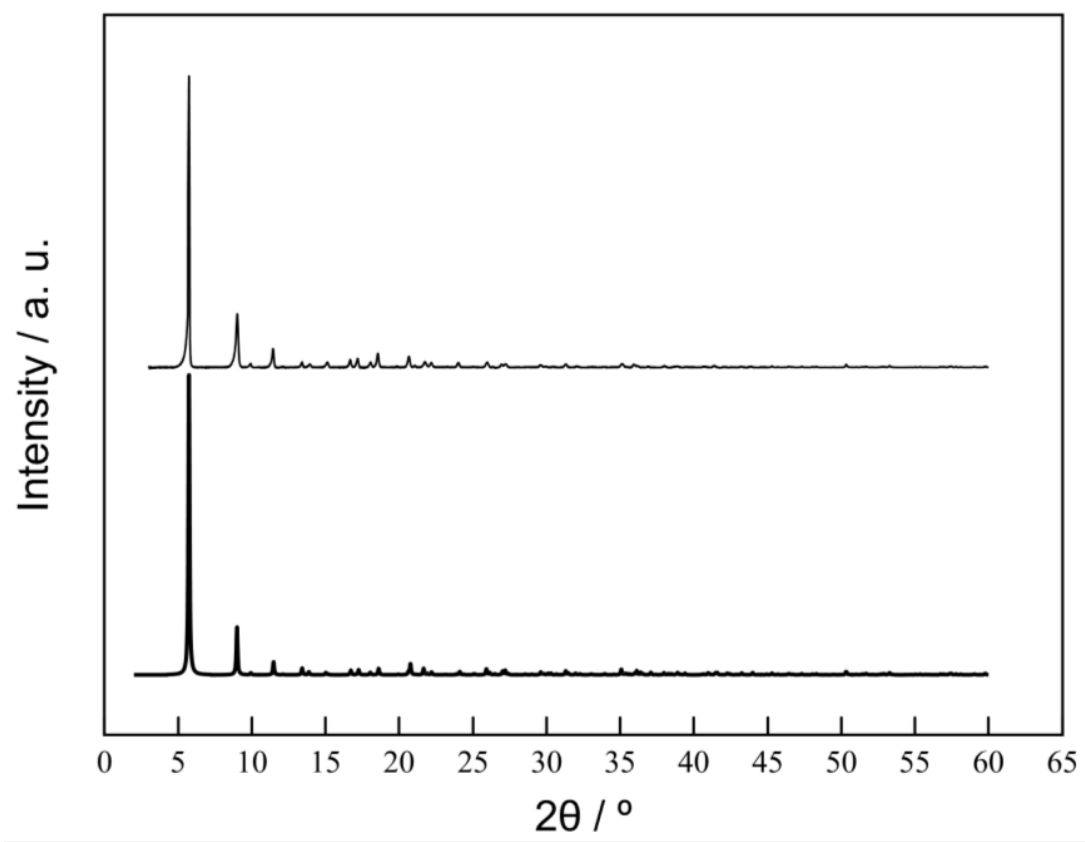

Figure S16. Theoretical PXRD pattern of 2 (bottom) and experimental PXRD pattern of the recycled 2 (top) in the $2.0-60.0^{\circ} 2 \theta$ range measured at room temperature. 

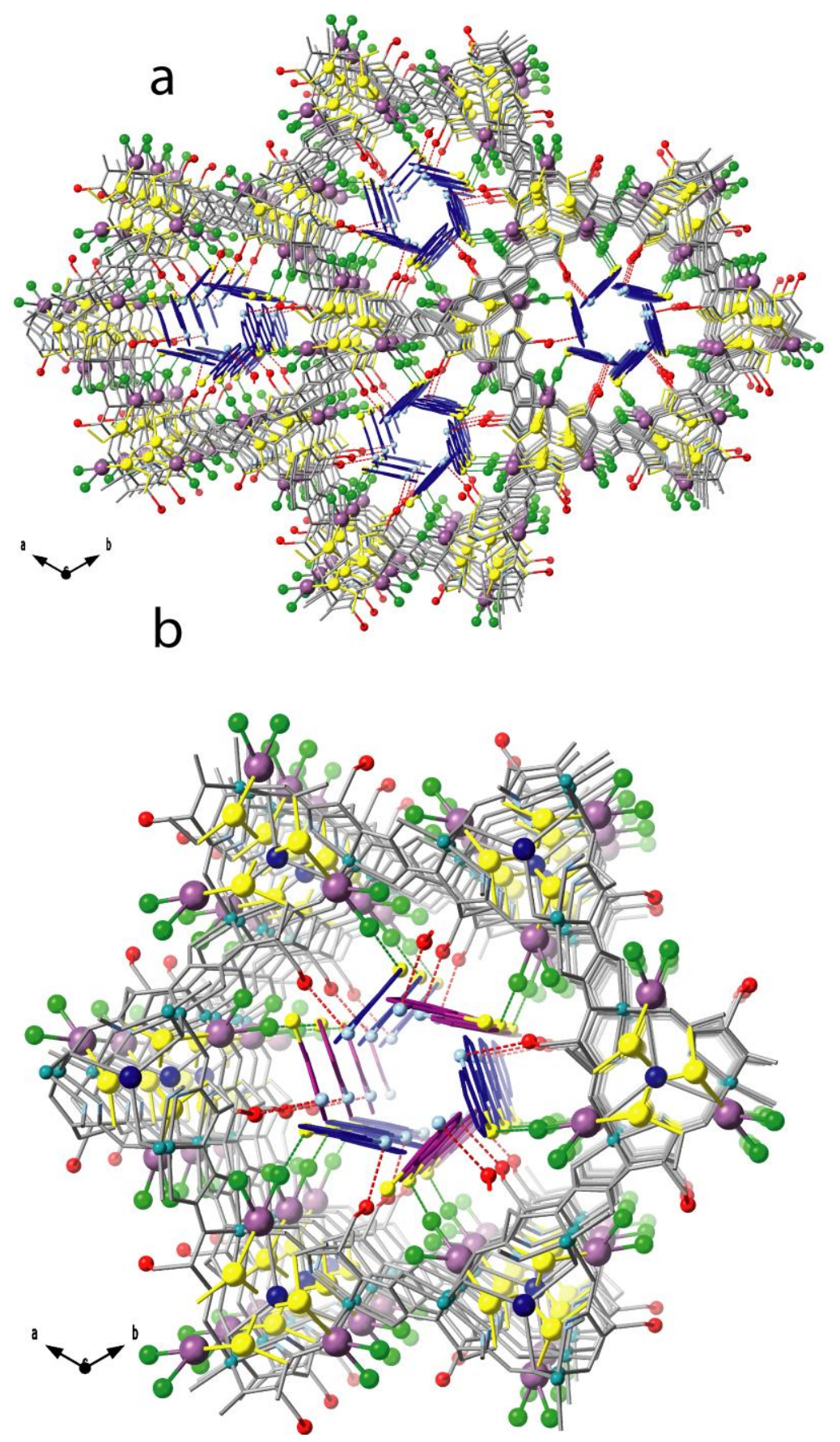

Figure S17. Perspective views of a portion (a) and a single channel (b) of the porous structure of the (MB)· $\mathbf{H g C l}_{2} @ 2$ adsorbate along the $c$ axis (the crystallization water molecules are omitted for clarity). clearly evidencing $\mathrm{HgCl}_{2}$ guest molecules held in the hexagonal nanopores of 2 , stabilized into the channels through $\mathrm{S} \cdots \mathrm{Hg}$ interactions together with $\mathrm{MB}$ molecules. Ligands from the network are depicted as gray stick with the exception of the $L$-serine $\left(-\mathrm{CH}_{2} \mathrm{OH}\right)$ and $L$-methionine $\left(-\mathrm{CH}_{2} \mathrm{CH}_{2} \mathrm{SCH}_{3}\right)$ residues, which are represented as red and yellow sticks, respectively. Copper(II) and calcium(II) ions from the network are represented as cyan and blue spheres, respectively. Oxygen and sulfur atoms from the residues are shown as red and yellow spheres, respectively. Mercury(II) and chlorine atoms are depicted as magenta and green spheres. Carbon atoms of organic dyes are depicted as blue or magenta sticks to underline the two configuration sets (see figure S5 and S6 for details). N $\cdots \mathrm{O}$ and $\mathrm{Hg} \cdots \mathrm{S}$ are depicted as red and yellow dashed lines respectively whereas $\mathrm{Cl} \cdots \mathrm{S}$ between inorganic $\mathrm{HgCl}_{2}$ molecules and organic dyes are depicted as green dashed lines. 

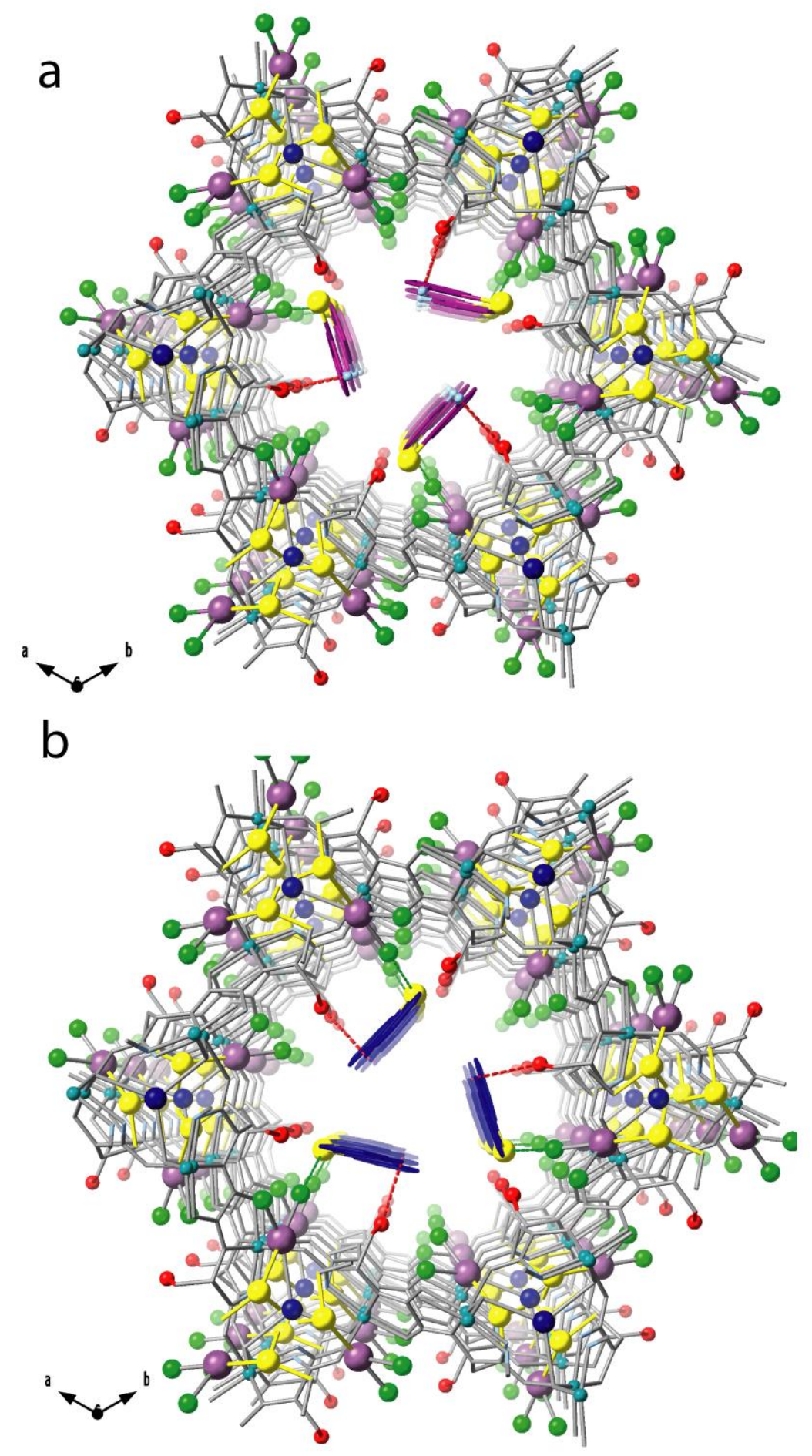

Figure S18. Perspective views of a single channel of the porous structure of the (MB) $\cdot \mathbf{H g C l}_{2} @ 2$ adsorbate along the $c$ axis (the crystallization water molecules are omitted for clarity) showing the two possible orientations of dyes molecules represented in (a) and (b), with magenta and blue sticks, respectively. Ligands from the network are depicted as gray stick with the exception of the $L$-serine ($\left.\mathrm{CH}_{2} \mathrm{OH}\right)$ and $L$-methionine $\left(-\mathrm{CH}_{2} \mathrm{CH}_{2} \mathrm{SCH}_{3}\right)$ residues, which are represented as red and yellow sticks, respectively. Copper(II) and calcium(II) ions from the network are represented as cyan and blue spheres, respectively. Mercury(II) and chlorine atoms are depicted as magenta and green spheres. Oxygen and sulphur atoms from the residues are shown as red and yellow spheres, respectively. $\mathrm{N} \cdots \mathrm{O}$ and $\mathrm{Hg} \cdots \mathrm{S}$ are depicted as red and yellow dashed lines respectively whereas $\mathrm{Cl} \cdots \mathrm{S}$ between inorganic $\mathrm{HgCl}_{2} \mathrm{molecules}$ and organic dyes are depicted as green dashed lines. 

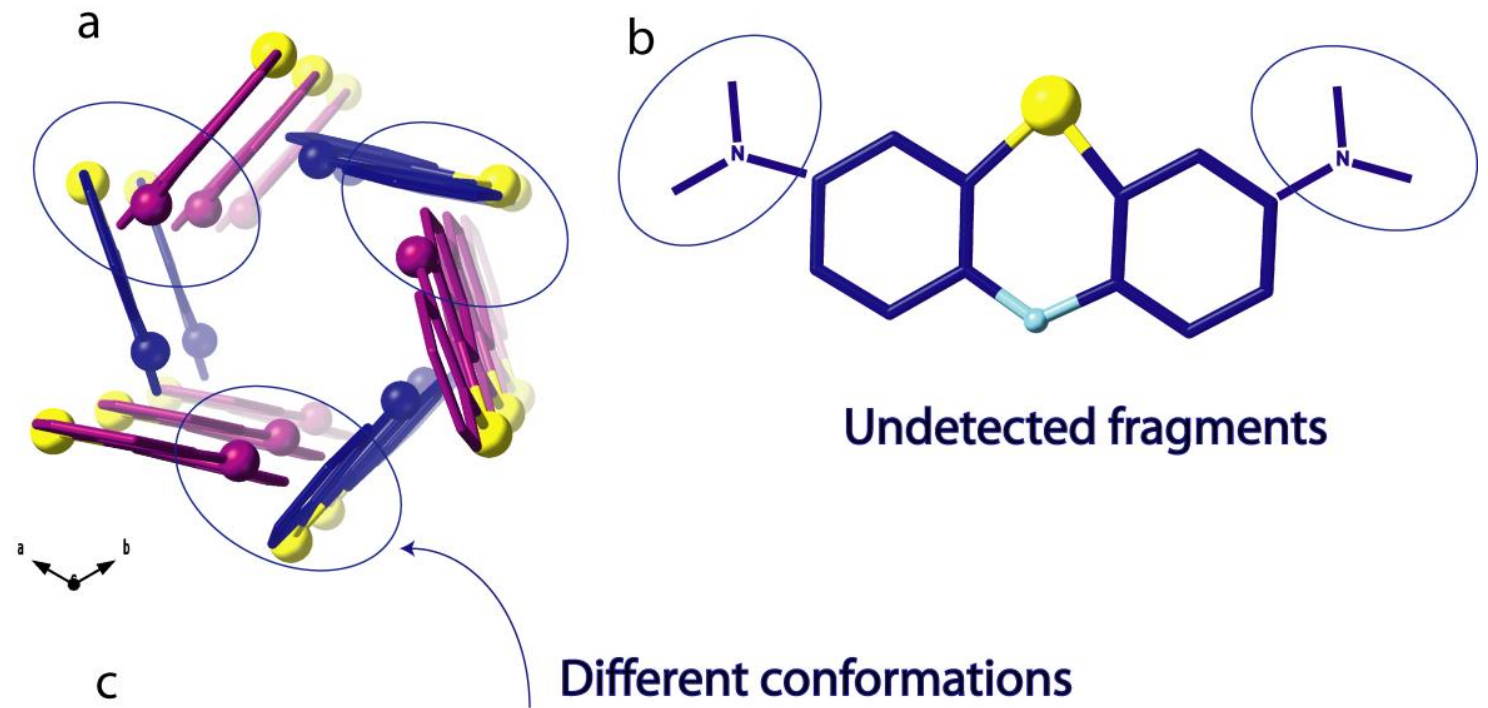

\section{Undetected fragments}

Different conformations

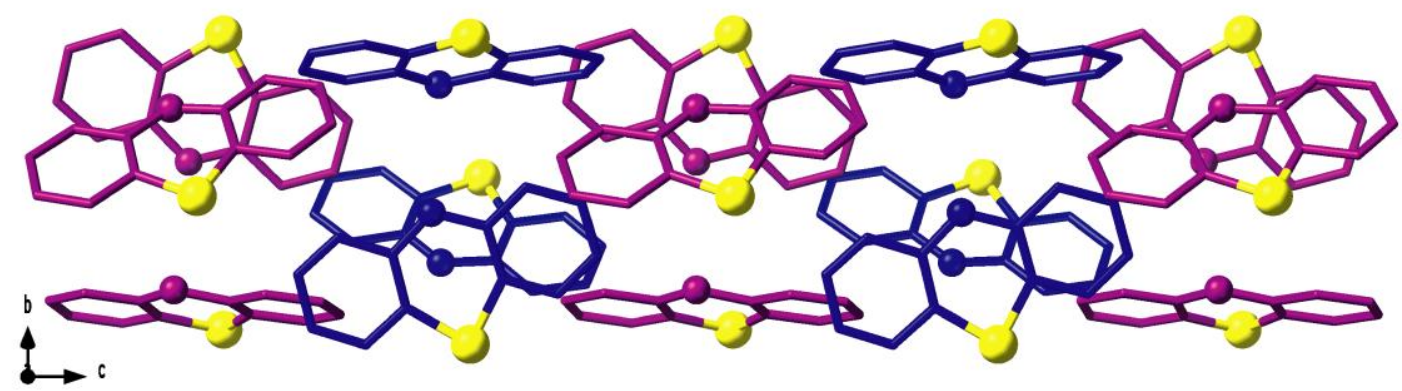

Figure S19. Details of the two sets of guest conformations in (MB) $\cdot \mathbf{H g C l}_{2} @ 2$. (a) Both configurations statistically disordered in pores. (b) Details of disordered guest molecule showing undetected fragments. (c) Arrangements of Methylene Blue molecules packed and propagating along the direction of channels (all possible orientations are included, represented in blue and magenta). Sulfur atoms are represented as yellow spheres whereas nitrogen as blue or magenta spheres (depending on configuration sets). 

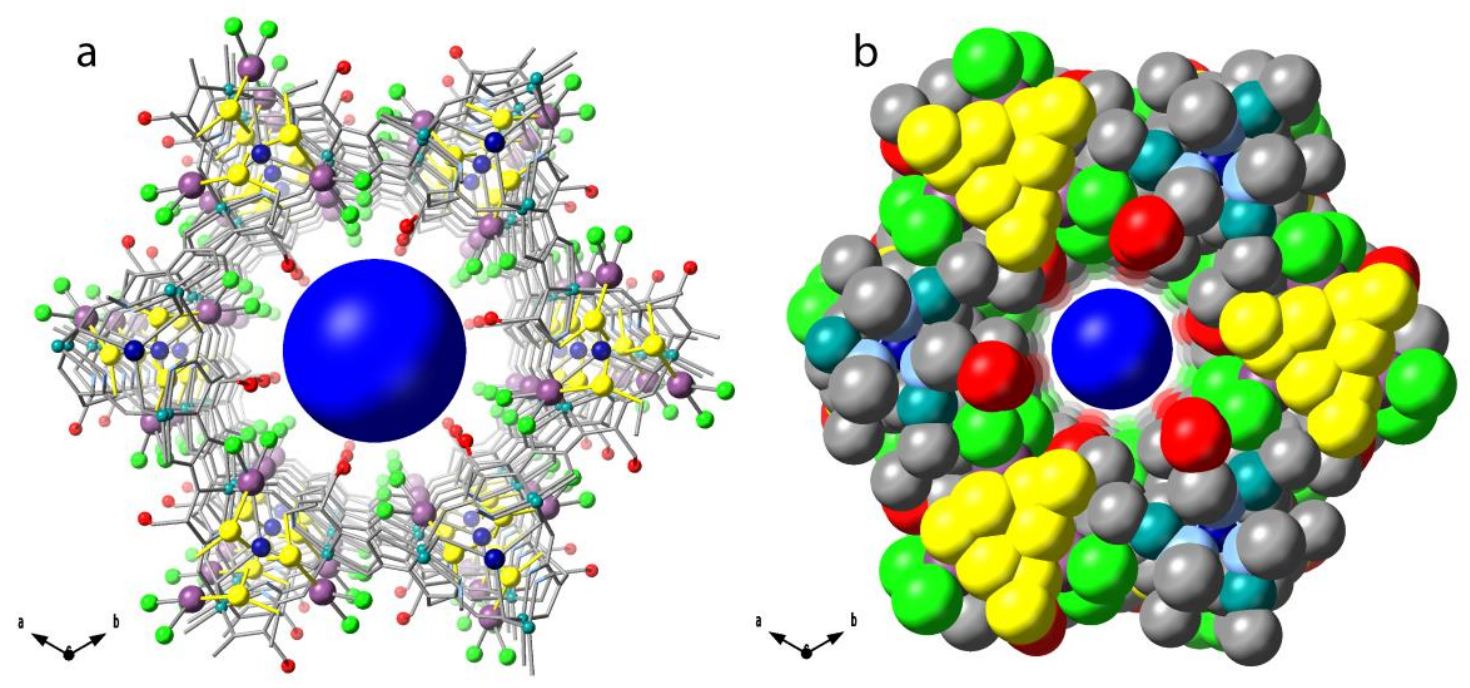

Figure S20. Perspective views in ball and sticks (a) and space filling (b) models of a single channel in (MB)· $\mathbf{H g C l}_{2} @ \mathbf{2}$ where Methylene Blue molecules have been omitted to underline the high porosity after inorganic guest inclusion. 


\section{References}

(1) Mon, M.; Ferrando-Soria, J.; Grancha, T.; Fortea-Pérez, F. R.; Gascon, J.; Leyva-Pérez, A.; Armentano, D.; Pardo, E. Selective Gold Recovery and Catalysis in a Highly Flexible Methionine-Decorated Metal-Organic Framework. J. Am. Chem. Soc. 2016, 138 (25), 7864-7867.

(2) Mon, M.; Bruno, R.; Ferrando-Soria, J.; Bartella, L.; Di Donna, L.; Talia, M.; Lappano, R.; Maggiolini, M.; Armentano, D.; Pardo, E. Crystallographic Snapshots of Host-guest Interactions in Drugs@ @etal-organic Frameworks: Towards Mimicking Molecular Recognition Processes. Mater. Horizons 2018.

(3) (a) Evans, P. Sclaing and assessment of data quality. Acta Cryst. D 62, 72-82 (2006). (b) Evans, P. R., Murshudov, G. N. How good are my data and what is the resolution?. Acta Cryst. D 69, 1204-1214 (2013). (c) Winn, M. D.; Ballard, C. C.; Cowtan, K. D.; Dodson, E. J.; Emsley, P.; Evans, P. R.; Keegan, R. M.; Krissinel, E. B.; Leslie, A. G. W.; McCoy, A.; McNicholas, S. J.; Murshudov, G. N.; Pannu, N. S.; Potterton, E. A.; Powell, H. R.; Read, R. J.; Vagin, A.; Wilsonc K. S. Overview of the CCP4 suite and current developments. Acta Cryst. D 67, 235-242 (2011). (d) Winter, G. xia2: and expert system for macromolecular crystallography data reduction. J. Appl. Cryst. 43, 186-190 (2010). (e) Winter, G.; Waterman, D. G.; Parkhurst, J. M.; Brewster, A. S.; Gildea, R. J.; Gerstel, M.; Fuentes-Montero, L.; Vollmar, M.; Michels-Clark, T.; Young, I. D.; Sauterb, N. K.; Evansa, G. DIALS: implementation and evaluation of a new integration package Acta Cryst. 2018, D74, 85-97

(4) SAINT, version 6.45, Bruker Analytical X-ray Systems, Madison, WI, 2003.

(5) Sheldrick G.M. SADABS Program for Absorption Correction, version 2.10, Analytical X-ray Systems, Madison, WI, 2003.

(6) (a) Sheldrick, G. M. Crystal structure refinement with SHELXL. Acta Cryst. C 71, 3-8 (2015). (b) Sheldrick, G. M. A short history of SHELX. Acta Cryst. A 64, 112-122 (2008). (c) SHELXTL-2013/4, Bruker Analytical X-ray Instruments, Madison, WI, 2013.

(7) (a) Spek, A. L. PLATON SQUEEZE: a tool for the calculation of the disordered solvent contribution to the calculated structure factors. Acta Crystallogr. Sect. C-Struct. Chem. 71, 9-18 (2015). (b) Spek, A. L. Structure validation in chemical crystallography. Acta Crystallogr. Sect. D, Biol. Crystallogr. 65, 148-155 (2009).

(8) Farrugia, L. J. WinGX suite for small-molecule single-crystal crystallography. J. Appl. Crystallogr. 32, 837-838 (1999).

(9) Palmer, D. CRYSTAL MAKER, Cambridge University Technical Services, C. No Title, 1996. 